\title{
COMMENTS
}

\section{THE COST OF CLOSURE: A REEXAMINATION OF THE THEORY AND PRACTICE OF THE 1996 AMENDMENTS TO THE FOREIGN SOVEREIGN IMMUNITIES ACT}

\section{S. JASON BALETSA ${ }^{\dagger}$}

[The law g]ave me a weapon. In other words, a-a sovereign country has the right to launch Tomahawk missiles at another country to protect its rights .... I don't have that kind of power. I don't have $\$ 60$ million to launch those kinds of missiles. But now I have something that's purely American. I have-I have American jurisdiction over the people who sponsored the terrorist attack which killed Alisa.

$$
\text { Stephen Flatow }{ }^{1}
$$

\section{INTRODUCTION}

In April 1995, a terrorist van packed with explosives collided into a bus in Israel killing seven Israeli soldiers and one American citizen. ${ }^{2}$ The American victim of this suicide bombing was Alisa Flatow, an undergraduate student at Brandeis University. ${ }^{3}$ In a world grown far too immune to such terrorist attacks, Stephen Flatow, Alisa's father, decided not to let his daughter's death become just another example of the turbulent peace process in the Middle East. Instead, he sought information, hoping to provide closure and accountability for his family's loss. With the assistance of Senator Frank Lautenberg of New Jersey and the cooperation of the State Department's top counter-

†J.D. Candidate 2000, University of Pennsylvania; B.A. 1997, University of Pennsylvania. I would like to thank Professor Harry Reicher for his comments and suggestions. I am indebted to Executive Editor Joann Yeh, Comments Editors Phyllis Staub and Amy Cuthrell, and all of the Associate Editors of the University of Pennsyluania Lau Review for their hard work and dedication.

${ }^{1} 60$ Minutes: In Memory of Alisa (CBS television broadcast, Oct. 4, 1998), available in LEXIS, News, Transcripts, CBS News Transcripts [hereinafter60 Minutes].

${ }^{2}$ See Gaza Bombing Viclim Buried in New Jersey, WASH. POST, Apr. 13, 1995, at A24; Michael Kranish, Use of Nations' Frozen Assels Poses Problem, BOSTON GLOBE, June 9, 1998, at Al.

${ }^{3}$ See Bella English, For Brandeis, Lost Innocence, BosTon Globe, Apr. 12, 1995, at 29 (reporting the effect of the news on fellow Brandeis students). 
terrorism task force, Stephen Flatow obtained the identity of his daughter's killer. To his surprise, the party ultimately responsible for the attack was not a person or group, but rather a nation-the Islamic Republic of Iran.

Outraged by this revelation, Stephen Flatow needed to take action. The Flatow family, however, in their pursuit to hold Iran accountable for Alisa's death, faced the ultimate David-and-Goliath challenge. What course of action could one family possibly take to hold a sovereign nation accountable for a terrorist attack? The answer-they sued Iran.

Requiring a sovereign nation to appear before domestic courts is not an easy task, but the Flatows were able to assert jurisdiction over Iran pursuant to recent amendments to the Foreign Sovereign Immunities Act of 1976 ("FSIA"). The first amendment, embedded in the Anti-Terrorism and Effective Death Penalty Act of 1996 ("AEDPA"), withdraws the cloak of sovereign immunity for foreign nations that sponsor acts of terrorism ${ }^{7}$ and permits the attachment of the foreign

${ }^{4}$ Stephen Flatow and the State Department "traced funds from Iran, bank by bank, account number by account number, to the terrorist organization [the Shiqaqi faction of the Palestine Islamic Jihad]." 60 Minutes, supra note 1. The Flatows then obtained copies of the Iranian budget for 1992 which blatantly noted an expenditure of $\$ 20$ million to support the Palestine Islamic revolution. See id.

${ }^{5}$ Foreign Sovereign Immunities Act of 1976, Pub. L. No. 94-583, 90 Stat. 2891 (codified at 28 U.S.C. $\$ \S 1330,1602-1611$ (1994)).

${ }^{6}$ Anti-Terrorism and Effective Death Penalty Act of 1996, Pub. L. No. 104-132, $\S 221,110$ Stat. 1214, 1241 (codified at 28 U.S.C. $\$ \$ 1605,1610$ (1994 \& Supp. III 1997)).

7 This amendment provides in pertinent part:

(a) A foreign state shall not be immune from the jurisdiction of courts of the United States or of the States in any case-

(7) not otherwise covered by paragraph (2), in which money damages are sought against a foreign state for personal injury or death that was caused by an act of torture, extrajudicial killing, aircraft sabotage, hostage taking, or the provision of material support or resources (as defined in section 2339A of title 18) for such an act if such act or provision of material support is engaged in by an official, employee, or agent of such foreign state while acting within the scope of his or her office, employment, or agency, except that the court shall decline to hear a claim under this paragraph-

(A) if the foreign state was not designated as a state sponsor of terrorism under section 6(j) of the Export Administration Act of 1979 (50 U.S.C. App. 2405(j)) or section 620A of the Foreign Assistance Act of 1961 (22 U.S.C. [\$] 2371) at the time the act occurred, unless later so designated as a result of such act; and

(B) even if the foreign state is or was so designated, if-

(i) the act occurred in the foreign state against which the claim has been brought and the claimant has not afforded the foreign state a rea- 
nation's assets or property in the United States for the purpose of satisfying any judgment rendered against it. ${ }^{8}$

With the shield of sovereign immunity removed, the Flatow family brought suit against Iran pursuant to another recent amendment to the FSIA, the Civil Liability for Acts of State-Sponsored Terrorism Act. ${ }^{9}$ This amendment, frequently referred to as the Flatow Amendment, ${ }^{10}$ creates a private cause of action against any official, employee, or agent of a foreign state who commits any act covered by AEDPA's terrorism exception to the FSIA, so long as that foreign state has been designated a state sponsor of terrorism. " Thus, AEDPA and the Flatow Amendment should be read together-the Flatow Amendment explicitly creates a private cause of action for acts that serve as the ba-

sonable opportunity to arbitrate the claim in accordance with accepted international rules of arbitration; or

(ii) neither the claimant nor the victim was a national of the United States (as that term is defined in section 101(a) (22) of the Immigration and Nationality Act) when the act upon which the claim is based occurred.

28 U.S.C. $\$ 1605$ (a) (7) (Supp. III 1997).

${ }^{8}$ AEDPA amended $\$ 1610$ (a) to provide:

(a) The property in the United States of a foreign state, as defined in section 1603(a) of this chapter, used for a commercial activity in the United States, shall not be immune from attachment in aid of execution, or from execution, upon a judgment entered by a court of the United States or of a State after the effective date of this act, if-

(7) the judgment relates to a claim for which the foreign state is not immune under section 1605 (a) (7), regardless of whether the property is or was involved with the act upon which the claim is based.

28 U.S.C. $\$ 1610$ (a)(7) (Supp. III 1997).

${ }^{9}$ This amendment provides in pertinent part:

an [sic] official, employee, or agent of a foreign state designated as a state sponsor of terrorism designated [sic] under section 6(j) of the Export Administration Act of 1979 [section 2405(j) of the Appendix to Title 50, War and National Defense] while acting within the scope of his or her office, employment, or agency shall be liable to a United States national or the national's legal representative for personal injury or death caused by acts of that official, employee, or agent for which the courts of the United States may maintain jurisdiction under section 1605 (a) (7) of title 28, United States Code, for money damages which may include economic damages, solatium, pain and suffering, and punitive damages if the acts were among those described in section 1605 (a) (7).

28 U.S.C. \$ 1605 note (Supp. III 1997) ("Civil Liability for Acts of State Sponsored Terrorism") (citing Foreign Operations, Export Financing, and Related Programs Appropriations Act of 1997, Pub. L. No. 104-208, division A, tit. I, § 101 (c) [tit. V, § 589], 110 Stat. 3009-172).

${ }^{10}$ See 60 Minutes, supra note 1 ("Congress in 1986 passed anti-terrorism legislation, including the Flatow Amendment, which allowed victims' families to sue foreign countries that sponsor terrorists.").

$"$ See 28 U.S.C. $\$ 1605$ note. 
sis for AEDPA's withdrawal of sovereign immunity.

While most of the initial scholarly commentary surrounding the passage of this anti-terrorist legislation focused on AEDPA's effects on writs of habeas corpus (Title II), the effect of these amendments on the doctrine of sovereign immunity was for the most part overlooked. $^{12}$ The commentary that did exist expressed varied opinions. Many saw this exception to sovereign immunity as "one of the crown jewels of the Anti-Terrorism legislation"1s that would ultimately deter future acts of terrorism and provide the closure and accountability the victims' families needed. ${ }^{14}$ Others, including the U.S. Department of State, were less jubilant about the vast theoretical implications of these amendments on the doctrine of sovereign immunity.

Regardless of the initial reaction, recent cases $^{16}$ filed pursuant to these amendments have added a practical dimension to the growing discourse on combating terrorism. ${ }^{17}$ These cases clearly demonstrate the failure of private suits to rectify the problem of state-sponsored terrorism. The inability of these lawsuits to effectuate their stated purpose, coupled with the theoretical concerns that many commentators have expressed, demonstrate that recourse to private suits for acts of state-sponsored terrorism must be reexamined.

This Comment explores both the theoretical implications and the practical consequences of private suits for acts of state-sponsored terrorism. Part I traces the evolution of the doctrine of sovereign immunity. From its early expression in judicial opinions to the emergence of the FSIA, the evolution of sovereign immunity has been gradual and deliberate. Part II, however, demonstrates how these recent

${ }^{12}$ See Allan Gerson, Holding Terrorist States Accountable, WASH. TmEs, June 4, 1996, at A15 (noting that "for all its importance, the new 'right to sue' provision has received scant notice in the popular press," and hypothesizing that the reason for this is the emphasis placed on the bill's provisions regarding habeas corpus relief).

${ }_{13} I d$.

${ }^{14}$ See id. ("It gives the victims of terrorism and their families what they desire most-accountability, the opportunity to get the true facts out in the open and thus to obtain closure to their own personal trials while at the same time preventing statesponsors of terrorism from evading responsibility.").

${ }^{15}$ See infra notes 274-77 and accompanying text (noting the State Department's resistance to the recent amendments).

${ }^{16}$ See, e.g., Cicippio v. Islamic Republic of Iran, 18 F. Supp. 2d 62 (D.D.C. 1998); Flatow v. Islamic Republic of Iran, 999 F. Supp. 1 (D.D.C. 1998); Alejandre v. Republic of Cuba, 996 F. Supp. 1239 (S.D. Fla. 1997). The most recent in this line of cases, filed too recently for treatment in the text, is Anderson v. Islamic Republic of Iran, C.A. No. 99 0698, 2000 U.S. Dist. LEXIS 3673 (D.D.C. Mar. 24, 2000).

${ }^{17}$ See infra Part III (analyzing the practical consequences of the recent suits under the 1996 amendments). 
amendments represent a fundamental and unwarranted deviation from this natural progression. While these amendments, in theory, attempt to rectify the problems that plagued private suits under the FSIA, the recent legislation simply goes too far. Part III of this Comment explores the practical consequences of private suits by examining recent cases filed pursuant to the Flatow Amendment. The emergence of this new judicial procedure was initially hailed as a triumph for those families touched by the horrors of international terrorism. In practice, however, such suits have resulted in unenforceable judgments that deny the victims' families the closure and accountability they desperately need. Finally, Part IV concludes by arguing that the theoretical implications of private suits, when viewed in conjunction with the results observed in practice, suggest a reexamination of the propriety of resorting to private suits. While such suits have highlighted the problem of international terrorism, they are clearly not the solution.

\section{THE GRADUAL EVOLUTION OF SOVEREIGN IMMUNITY}

\section{A. The Genesis of Absolute Immunity: The Schooner Exchange v. M'Faddon}

State sovereign immunity has rather enigmatic doctrinal origins. ${ }^{18}$ While one can see the emergence of this theory in the writings of philosophical theorists such as Grotius and Vattel, ${ }^{19}$ the first discernible articulation of this theory appears in the judicial opinions of the nineteenth century. ${ }^{20}$ Primarily, there are two areas in which the earliest manifestations of sovereign immunity are most evident: the protection afforded diplomatic agents ${ }^{21}$ and cases involving foreign public

${ }^{18}$ See Gamal Moursi BadR, State IMmunity: AN ANALYTICAL AND Prognostic VIEW 9 (1984) ("The genesis of the doctrine of state immunity is not readily discernible ...." $)$.

10 Hugo Grotius was a seventeenth-century philosopher who wrote one of the first treatises on sovereignty, DE IURE BELLI AC PACIS LIBRI TRES [THREE BOOKS ABOUT THE LAW OF WAR AND PEACE] (1625). Emerick de Vattel was an eighteenth-century philosopher who also illuminated the issue of state sovereignty in LE DROIT DES GENS, OU PRNCIPES DE IA LOI NATURELIE, APPLIQUÉS À LA CONDUITE ET AUX AFFAIRES DES NATIONS ET DES SOUVERAINS [THE LAW OF NATIONS OR THE PRINCIPLES OF NATURAL LAW APPLIED TO THE CONDUCT AND TO THE AFFAIRS OF NATIONS AND SOVEREIGNS] (1758). For a discussion of the importance of these philosophers to the development of state immunity, see BADR, supra note 18, at 9-12.

${ }^{20}$ See BADR, supra note 18 , at 9 ("[T] he rules of state immunity... have derived mainly from the judicial practice of individual nations since the nineteenth century.").

${ }^{21}$ See Charles J. LeWIS, STATE AND DIPLOMATIC IMMUNITY 20 (2d ed. 1985) ("The 
ships. ${ }^{22}$ In both scenarios, courts embraced an absolute theory of immunity which acknowledged that "all states are equal and that no one state may exercise authority over any other state."

American courts, in The Schooner Exchange v. M'Faddon, ${ }^{24}$ took the lead in delineating the doctrine of absolute sovereign immunity. ${ }^{25}$ In this case, the French navy captured the schooner Exchange, owned by John McFaddon and his partner, William Greetham, on the high seas and converted it into the French ship-of-war, the Balaou. ${ }^{26}$ Due to inclement weather, the Balaou was forced to enter the port of Philadelphia. While in U.S. territory, McFaddon and Greetham filed suit in federal court claiming that they were the sole owners of the vessel and that she was "violently and forcibly taken by certain persons, acting under the decrees and orders of Napoleon, Emperor of the French."

Chief Justice John Marshall, while noting that " $[t]$ he jurisdiction of the nation within its own territory is necessarily exclusive and absolute, ${ }^{, 28}$ wrote that in a world "composed of distinct sovereign[s], possessing equal rights and equal independence, ${ }^{\not 29}$ the jurisdiction of one sovereign "would not seem to contemplate foreign sovereigns, nor

doctrine of sovereign immunity found its earliest manifestation in the protection afforded to diplomatic agents.").

${ }^{22}$ See BADR, supra note 18 , at 16-18 (summarizing early admiralty cases raising the issue of sovereign immunity).

${ }^{29}$ LOUIS HENKIN ET AL., INTERNATIONAI LAW: CASES AND MATERIALS 1126 (3d ed. 1993).

${ }^{24} 11$ U.S. (7 Cranch) 116 (1812).

${ }^{25}$ This is not to suggest that the United States was alone in developing the theory of absolute immunity. The Supreme Court of France stated that "[ $t]$ he reciprocal independence of states is one of the most universally respected principles of international law, and it follows as a result therefore that a government cannot be subjected to the jurisdiction of another against its will ...." Spanish Government v. Lambege et Pujol, D. 1849, at 1, 5, 9, translated and excerpted in BARRY E. CARTER \& PHILIP R. TRIMBLE, INTERNATIONAL LAW 588 (2d ed. 1995). The British courts also addressed the theory of absolute immunity in The Parlement Belge, 5 P.D. 197 (1880) (Eng.). Lord Justice Brett wrote:

As a consequence of the absolute independence of every sovereign authority, and of the international comity which induces every sovereign state to respect the independence and dignity of every other sovereign state, each and every one declines to exercise by means of its Courts any of its territorial jurisdiction over the person of any sovereign ....

Id. at 214-15. For further discussion of the international development of absolute immunity, see JOSEPH M. SWEENEY, U.S. DEP'T OF STATE, THE INIERNATIONAL LAW OF SOVEREIGN IMMUNITY 20-21 (1963).

${ }^{26}$ See Schooner Exchange, 11 U.S. (7 Cranch) at 117 (setting forth the facts of the dispute).
${ }^{27}$ Id. at 116.
${ }^{23} I d$. at 136.
${ }^{29}$ Id. 
their sovereign rights as its objects." ${ }^{, 00}$ Thus, a foreign sovereign, equal in rights and independence to any other, enters the territory of another sovereign "only under an express license, or in the confidence that the immunities belonging to his independent sovereign station ... are reserved by implication, and will be extended to him."s1 Having articulated this theoretical basis of sovereign immunity, Marshall applied it to the present case and concluded that an armed ship in the service of a foreign sovereign "must be considered as having come into the American territory, under an implied promise, that while necessarily within it . . . she should be exempt from the jurisdiction of the country." ${ }^{32}$ Thus, the French government was immune from jurisdiction, and Marshall dismissed the case.

While there were many early attempts to limit the absolute immunity doctrine, few were successful. In Berizzi Bros. v. Steamship Pesaro, ${ }^{33}$ the district court seized upon language in Marshall's opinion in Schooner Exchange to deny immunity for a foreign ship that was engaged in a commercial activity. ${ }^{34}$ Upon review, the Supreme Court ${ }^{35}$ resisted limiting the absolute immunity doctrine and instead found that "merchant ships held and used by a government [in this case, Italy] ... must be held to have the same immunity as war ships, in the absence of a treaty or statute of the United States evincing a different purpose. ${ }^{36}$ While this attempt to restrict the absolute immunity doctrine failed, it did demonstrate that some restrictions were needed and foreshadowed their ultimate inevitability.

\section{B. Movement from Absolute to Restrictive Immunity: The Tate Letter}

Although one could hear rumblings of discontent in the judiciary, the first gradual deviation from the absolute doctrine came from the

so Id. at 137.

${ }^{31}$ Id.

${ }^{32}$ Id. at 147.

s3 277 F. 473 (S.D.N.Y. 1921).

34 In his opinion, Marshall stated: "Without indicating any opinion on this question, it may safely be affirmed, that there is a manifest distinction between the private property of the person who happens to be a prince, and that military force which supports the sovereign power and maintains the dignity and independence of a nation." Schooner Exchange, 11 U.S. (7 Cranch) at 145. Thus, while not serving as the basis for the decision here, this dictum articulates the restrictive theory of immunity, which would eventually replace the absolute theory 140 years later.

${ }^{95}$ See Berrizzi Bros. v. S.S. Pesaro, 271 U.S. 562 (1926).

${ }^{36}$ Id. at 574. 
executive branch through the Tate Letter. ${ }^{37}$ Jack Tate, serving as legal advisor to the State Department in 1952, wrote a letter to the Attorney General advising the United States to adopt a more restrictive theory of sovereign immunity that dichotomized acts into jure imperii [public acts] and jure gestionis [private acts]. ${ }^{38}$ Tate argued that the public acts of the sovereign should retain immunity in U.S. courts but that other private commercial acts should be subject to American jurisdiction. ${ }^{39}$

Tate advocated this approach for several reasons. First, he surveyed the various approaches of other nations and noted that several nations, including Belgium, Italy, France, Austria, Greece, Switzerland, and Egypt, had already adopted the restrictive theory. ${ }^{40}$ Second, Tate reasoned that the United States placed itself and its citizens at a disadvantage by waiving sovereign immunity in foreign courts while providing immunity for foreign sovereigns in domestic courts. ${ }^{41}$ Finally, Tate claimed that the increased commercialization of the world market, with nations themselves engaging in commercial activities, necessitated subjecting these nations to domestic jurisdiction so that any dispute would be within the purview of the courts. ${ }^{42}$

${ }^{37}$ Changed Policy Concerning the Granting of Sovereign Immunity to Foreign Governments, May 19, 1952, DEP'T ST. BuLL., June 1952, at 984 [hereinafter Tate Letter].

ss See id. (distinguishing this restrictive theory of immunity from "the classical or absolute theory of sovereign immunity, [which holds] a sovereign cannot, without his consent, be made a respondent in the courts of another sovereign").

${ }^{39}$ See id. ("[T] he immunity of the sovereign is recognized with regard to sovereign or public acts ... of a state, but not with respect to private acts.").

${ }_{40}$ See id. ("The ... restrictive theory... has always been supported by ... Belgium and Italy. It was adopted in ... Egypt and . . . Switzerland. ... France and Austria [adopted it] in the 20's. ... Rumania, Peru, and ... Denmark also appear to follow this theory.").

12

[T] he granting of sovereign immunity to foreign governments in the courts of the United States is most inconsistent with the action of the Government of the United States in subjecting itself to suit ... and with its long established policy of not claiming immunity in foreign jurisdictions for its merchant vessels.

See id. at 985.

${ }^{42}$ See id. (" $[\mathrm{W}]$ idespread and increasing activity on the part of governments of engaging in commercial activities makes necessary a practice which will enable persons doing business with them to have their rights determined in the courts."); see also David MacKusick, Comment, Human Rights vs. Sovereign Rights: The State Sponsored Terrorism Exception to the Foreign Sovereign Immunities Act, 10 EMORY INT'L L. REV. 741, 752 (1996) (noting that the era of laissez-faire economics which thrived in the late nineteenth century was replaced by the "re-entry of the state into the marketplace, and most notably, the emergence of socialist states with state trading companies"). As a result, it became profoundly unfair to subject "a private trader to legal responsibility while grant- 
Translating the restrictive theory into practice proved to be problematic for American courts, which had trouble distinguishing between public and private acts. ${ }^{43}$ As a result, the decision where to draw the line between public and private was left to the State Department. A foreign state would "request[] the State Department to ask the Department of Justice to make a 'suggestion of immunity' to the court."14 The Supreme Court held that such a suggestion would be given great deference since it represented "'a conclusive determination by the political arm of the Government' that proceeding with the suit 'interferes with the proper conduct of our foreign relations." $"$ t5

Although to many the Tate Letter represented formal acceptance of the restrictive theory of immunity, some commentators contend that the case law following the issuance of the Tate Letter does not reflect such a doctrinal shift. ${ }^{46}$ Not only was the reluctance to accept the theory reflected in the case law, but the actions of the United States, in defending itself in foreign courts, demonstrate that full allegiance to the restrictive theory would not occur for at least thirty years. ${ }^{47}$ The transformation from absolute to restrictive sovereign immunity thus progressed gradually until formal codification of the restrictive theory in 1976.

ing immunity to a government engaged in the same transaction." Id.

${ }^{43}$ See M. Scott Bucci, Comment, Breaking Through the Immunity Wall?: Implications of the Terrorism Exception to the Foreign Sovereign Immunities Act, 3J. INT'L LEGAL STUD. 293, 299 (1997) ("The federal courts had difficulty distinguishing between the two categories." (citing Margot C. Wuebbels, Commercial Terrorism: A Commercial Activity Exception Under $\$ 1605(a)(2)$ of the Foreign Sovereign Immunities Act, 35 ARIZ. L. REV. 1123, 1130 (1993))).

14 RESTATEMENT (THIRD) OF THE FOREIGN RELATIONS LAW OF THE UNITED STATES, pt. IV, ch. 5, introductory note (1986).

${ }^{15}$ Id. (quoting Ex parte Republic of Peru, 318 U.S. 578, 588-89 (1943)); see also Republic of Mexico v. Hoffman, 324 U.S. 30, 35-36 (1945) (recognizing judicial deference to the State Department to define the limits of sovereign immunity).

${ }^{16}$ See BADR, supra note 18 , at 54 (noting that prior to 1976 and the enactment of the FSIA, the case law does not reflect a complete shift from absolute to restrictive immunity).

${ }^{47}$ The House Report to the FSIA demonstrates that in the 1950s, the United States would instruct foreign counsel to plead sovereign immunity in every case. In the 1960s, the United States abandoned this approach in countries that had already adopted the restrictive principle but invoked absolute immunity in those countries that did not. Finally, in the 1970s, the United States, regardless of the foreign forum's policy, did not invoke absolute immunity abroad in instances where the United States, pursuant to the Tate Leller, would not recognize a foreign state's immunity in domestic courts. See H.R. REP. No. 94-1487, at 9 (1976), reprinted in 1976 U.S.C.C.A.N. 6604, 6608. 


\section{Codification of Restrictive Immunity: The Foreign Sovereign Immunities Act of 1976}

The problems that persuaded the United States to accept the restrictive theory in the 1950s were further exacerbated in the 1970s. Due to the increasing globalization of American interests, Congress needed clear legal standards that signified formal recognition of the restrictive theory and placed the United States on even footing with other nations. ${ }^{48}$ This was the main objective of the Foreign Sovereign Immunities Act of $1976 .^{49}$

During hearings surrounding the passage of the FSIA, Monroe Leigh, the legal adviser of the U.S. Department of State, highlighted the problems of applying a non-statutory-based, restrictive theory of sovereign immunity. Leigh argued that the granting of sovereign immunity at the behest of those foreign nations that request suggestions of immunity from the Justice Department was an inefficient and problematic system. ${ }^{50}$ Furthermore, the United States, although providing recourse to diplomatic concerns for other countries subject to suit in domestic courts, could not avail itself of similar treatment abroad since "[i]n virtually every other country in the world, sovereign immunity is a question of international law decided exclusively by the courts and not by institutions concerned with foreign affairs. ${ }^{, 51}$

Leigh also noted that the lack of any clear acceptance of the restrictive theory of sovereign immunity created problems for private citizens engaged in international commerce. ${ }^{52}$ Leigh argued that the

${ }^{18}$ See Jurisdiction of U.S. Courts in Suits Against Foreign States: Hearings on H.R. 11315 Before the Subcomm. on Admin. Law and Governmental Relations of the House Comm. on the Judiciary, 94th Cong. 24, 26-27 (1976) (statement of Monroe Leigh, Legal Advisor, U.S. Department of State) [hereinafter Leigh Testimony] (articulating his dissatisfaction with the consequences of the Tate Letter).

${ }^{49}$ See Republic of Argentina v. Weltover, Inc., 504 U.S. 607, 612 (1992) (stating that "the [Foreign Sovereign Immunities] Act ... largely codifies the so-called 'restrictive' theory of foreign sovereign immunity first endorsed by the State Department in 1952"); see also The Foreign Sovereign Immunities Act: Hearing on S. 825 Before the Subcomm. on Courts and Admin. Practice of the Senate Comm. on the Judiciary, 103d Cong. 12 (1994) (statement of Jamison S. Borek, Deputy Legal Advisor, U.S. Department of State) [hereinafter Borek Statement] (noting that the primary objective of the FSIA was "to codify the 'restrictive' principle of sovereign immunity as recognized in international law").

${ }^{50}$ See Leigh Testimony, supra note 48, at 26-27 (pinpointing the various considerations of leaving the diplomatic initiative to the foreign state).

si $I d$. at 27.

${ }^{52}$ See id. (urging Congress to adopt the FSIA in order to provide uniformity and certainty to a growing number of private citizens who conduct business with foreign nations). Leigh reasoned that "when the foreign state enters the marketplace or when 
lack of formal standards for granting immunity might deny a private citizen a legal remedy in domestic courts since " $[\mathrm{h}] \mathrm{e}$ cannot be entirely certain that the ordinary legal dispute will not be artificially raised to the level of a diplomatic problem through the government's intercession with the State Department. ${ }^{353}$ Thus, Congress passed the FSIA in order to replace ad hoc case-by-case diplomatic determinations and to provide private citizens with recourse to a domestic forum for a determination of their legal disputes with foreign nations. ${ }^{54}$

Once signed into law, the FSIA became the sole means of exercising jurisdiction over a foreign sovereign in the United States. ${ }^{55}$ The basic premise of the FSIA is that the restrictive theory of sovereign immunity applies to all suits brought against foreign nations. ${ }^{56}$ While the Tate letter argued for immunity based upon the distinction between public versus private acts, the FSIA states that foreign nations are presumptively immune from American jurisdiction unless the alleged act falls within one of the narrowly-tailored exceptions. ${ }^{57}$ The exceptions from immunity, as originally enacted, included explicit and implicit waivers of immunity; commercial activity which directly or indirectly affects the United States; expropriation; property claims; noncommercial torts; admiralty claims; counterclaims; and international agreements. ${ }^{58}$ Thus, through the FSIA's limited and carefully enumerated exceptions, the theory of sovereign immunity gradually

it acts as a private party, there is no justification in modern international law for allowing the foreign state to avoid the economic costs of the agreements which it may breach or the accidents which it may cause." Id.

${ }^{33}$ Id.

${ }^{34}$ See H.R. REP. NO. 94-1487, at 7 (1976), reprinted in 1976 U.S.C.C.A.N. 6604, 6606 (stating that an important purpose of the FSIA "is to transfer the determination of sovereign immunity from the executive branch to the judicial branch, thereby reducing the foreign policy implications of immunity determinations and assuring litigants that these often crucial decisions are made on purely legal grounds and under procedures that insure due process").

${ }^{53}$ See id. at 12 (stating that the FSIA "sets forth the sole and exclusive standards to be used in resolving questions of sovereign immunity raised by foreign states before Federal and State courts in the United States"); see also Argentine Republic v. Amerada Hess Shipping Corp., 488 U.S. 428, 443 (1989) (noting that after passage of the FSIA, neither the Alien Torts Claims Act nor any other federal statute may serve as the basis for jurisdiction against a foreign state).

${ }_{36}$ See Verlinden B.V. v. Central Bank of Nig., 461 U.S. 480, 488 (1983) (explaining that "[f]or the most part, the Act codifies, as a matter of federal law, the restrictive theory of sovereign immunity").

${ }^{37}$ See 28 U.S.C. \$ 1604 (1994 \& Supp. III 1997) (stating that "a foreign state shall be immune from the jurisdiction of the courts of the United States and of the States except as provided in sections 1605 to 1607 of this chapter").

${ }^{35}$ See id. $\$ 1605$ (enumerating the exceptions to sovereign immunity claims). 
evolved from absolute to restrictive.

\section{The Non-Commercial Tort Exception and Private Suits for Acts of Terrorism}

The "non-commercial tort exception" provides that a sovereign nation is not immune from suit where money damages are sought against that foreign nation for personal injury or death, or damage to or loss of property. These limitations on immunity require further that such incidents occur in the United States and be caused by the tortious act or omission of the foreign state or of any official or employee of the foreign state while acting within the scope of his office or employment. ${ }^{59}$

While the legislative history suggests that the non-commercial tort exception was "directed primarily at the problem of traffic accidents, ${ }^{, 60}$ many private litigants claimed this section as the jurisdictional basis for private civil suits alleging terrorist activity. The noncommercial tort exception, however, has jurisdictional limitations that drastically limit its application to acts of state-sponsored terrorism.

The most severe limitation of the non-commercial tort exception is that it provides liability for non-commercial torts only when the tort occurs, in its entirety, in the United States. ${ }^{61}$ Therefore, if the alleged tortious conduct occurred in the defendant state, foreign territory, or international waters, a litigant cannot avail himself of this exception to the FSIA. ${ }^{62}$ Although such a territorial requirement "is not clear from

${ }^{59}$ See id. $\$ 1605(\mathrm{a})(5)$.

${ }^{60}$ Borek Statement, supra note 49, at 13 ("The purpose of section 1605 (a) (5) [was] to permit the victim of a-traffic accident or other noncommercial tort to maintain an action against the foreign state to the extent otherwise provided by law."); see also CHRISTOPH H. SCHREUER, STATE IMMUNITY: SOME RECENT DEVELOPMENTS 44 (1988) (noting that " $[t]$ he torts exception was meant to cover situations like motor or other accidents").

${ }^{61}$ See 28 U.S.C. $\$ 1605$ (a) (5) (stating that liability is possible when "money damages are sought against a foreign state for personal injury or death, or damage to or loss of property, occurring in the United States" (emphasis added)).

${ }^{62}$ See Siderman de Blake v. Republic of Argentina, 965 F.2d 699, 710-11 (9th Cir. 1992) (discussing the requirement of "direct effect" in the United States); Persinger v. Islamic Republic of Iran, 729 F.2d 835, 839 (D.C. Cir. 1984) (holding that tortious conduct committed on the grounds of a U.S. embassy does not qualify for relief under FSIA); McKeel v. Islamic Republic of Iran, 722 F.2d 582, 587 (9th Cir. 1983) ("Under the FSIA, sovereign immunity is waived in suits [for damages] occurring in the United States.") (citation and internal quotation omitted); see also Gerson, supra note 12, ("[U]nless the act occurred within the territorial confines of the United States the terrorist state could, in effect, admit culpability and walk away from any accountability."). But see Frolova v. USSR, 761 F.2d 370, 379-80 (7th Cir. 1985) (noting that although 
the language of the statute, ${ }^{, 63}$ most courts have relied upon the House Report, which explicitly states that the alleged tortious activity must have occurred in the United States, in finding that such a requirement exists. ${ }^{64}$

The case of Smith v. Socialist People's Libyan Arab Jamahiriya $a^{65}$ provides perhaps the most devastating example of the inability of the FSIA to accommodate private suits for acts of terrorism. This case was one of a barrage of lawsuits filed in the aftermath of the bombing of Pan Am Flight 103. ${ }^{66}$ The named plaintiffs in the suit, Bruce Smith and Paul Hudson, who both lost their wives in the bombing, claimed that Libya sponsored the attack despite adamant denials by the Libyan government. ${ }^{67}$ Libya filed a motion to dismiss the case, claiming (among other things) that the United States lacked jurisdiction over it based upon the tenets of sovereign immunity as outlined in the FSIA. ${ }^{69}$ The district court agreed with Libya's jurisdiction argument and dis-

there is sovereign immunity for activities wholly outside American territory, if such activity has a "direct effect in the United States," such immunity is waived).

${ }^{63}$ MacKusick, supra note 42 , at 754.

${ }^{64}$ See H.R. REP. No. 94-1487, at 21 (1976), reprinted in 1976 U.S.C.C.A.N. 6604, 6619 ("[T] States"). The Supreme Court addressed the issue of the territorial restriction of the non-commercial tort exception in Argentine Republic v. Amerada Hess Shipping Corp., 488 U.S. 428 (1989). In this case, a Liberian oil tanker, chartered by Amerada Hess, was attacked in international waters by Argentinean aircraft. Stating that "the FSIA provides the sole basis for obtaining jurisdiction over a foreign state" and finding that "respondents' injury unquestionably occurred well outside the 3-mile limit then in effect for the territorial waters of the United States," the Supreme Court held that "the exception for noncommercial torts cannot apply" and dismissed the complaint for lack of jurisdiction. Id. at $439,441$.

${ }_{65} 886$ F. Supp. 306 (E.D.N.Y. 1995). For a complete analysis of the background of this case and its implications for sovereign immunity, see Leslie McKay, Comment, $A$ New Take on Antiterrorism: Smith v. Socialist People's Libyan Arab Jamahiriya, 13 AM. U. INT'L L. REV. 439, 449-54 (1997).

${ }^{65}$ See Toni Locy, Families Suing Libya over Pan Am Blast, WASH. POST, May 7, 1996, at A13 (noting the various lawsuits that were filed in the aftermath of the bombing). While more than 10 years have passed since Pan Am Flight 103 exploded over Lockerbie, Scotland, there has been little closure for victims' families. See Mitch Stacy, Lockerbie Victims Mourmed 10 Years After, CHI. SUN-TMMES, Dec. 21, 1998, at 12 (pointing out that 10 years after the explosion, Libyan suspects had yet to be handed over for trial).

${ }^{67}$ See Smith, 886 F. Supp. at 309 (quoting allegations from the complaints of Smith and Hudson); McKay, supra note 65, at 441 ("Maintaining that it condemns all terrorist activities, Libya ... firmly denies any connection with the Pan Am bombing.") (citation omitted).

${ }^{\Leftrightarrow}$ See Smith, 886 F. Supp. at 309 (outlining Libya's argument for lack of subject matter jurisdiction based upon the FSIA and customary principles of international law). 
missed the case. ${ }^{69}$

The plaintiffs appealed the case to the Second Circuit. ${ }^{70}$ In order to overcome the jurisdictional obstacle, the plaintiffs attempted to employ four variations of the FSIA:

(1) implied waiver of immunity under the FSIA arising from Libya's alleged participation in actions that violate jus cogens norms; (2) implied waiver of immunity under the FSIA arising from Libya's alleged guaranty of any damage judgment against defendants al-Megrahi and Fhima; (3) the occurrence of the bombing on "territory" of the United States; and (4) the argument that Libya's immunity conflicts with the United Nations Charter.

The Second Circuit was not persuaded by any of these claims and affirmed the lower court's dismissal of the action. ${ }^{72}$ The amalgam of claims the plaintiffs were forced to raise in order to assert a claim against Libya shows how poorly the FSIA covered acts of statesponsored terrorism. ${ }^{73}$ Unless the plaintiff managed to neatly fit his claim within one of the enumerated exceptions, the claim was barred. $^{74}$

${ }^{69}$ The Smith court concluded:

Although Libya's alleged participation, if true, in this tragedy is outrageous and reprehensible ... this Court may not rightly obtain jurisdiction over Libya for the purposes of these private rights of action. Libya's alleged terrorist actions do not fall within the enumerated exceptions to the [FSIA] and therefore Libya must be accorded sovereign immunity from suit.

Id. at 315 .

${ }^{70}$ See Smith v. Socialist People's Libyan Arab Jamahiriya, 101 F.3d 239 (2d Cir. 1996).

7 McKay, supra note 65, at 449-50; see also Smith, 101 F.3d at 242-46 (analyzing the merits of the four claims).

${ }^{72}$ See Smith, 101 F.3d at 247.

73 See Bucci, supra note 43 , at 313 (claiming that prior to AEDPA, "victims had to shape their claim so that it could be pigeonholed into one of the existing exceptions to the FSIA," and noting that "rarely were these efforts successful").

${ }^{74}$ Furthermore, the court created an even greater obstacle to pursuing private suits for acts of state-sponsored terrorism through the FSIA by stating that Congress did not intend the FSIA to be used as a sword to pierce the veil of sovereign immunity in this context. Instead, the court felt as if the response to terrorist activity was properly placed within the purview of the executive and legislative branches. See Smilh, 101 F.3d at 244 ("Congress may well have expected the response to such violations to come from the political branches of the Government, which are not powerless to penalize a foreign state for international terrorism."). Thus, the precedential authority of Smith became an obstacle to future private suits. 


\section{The Recent Amendments to the Foreign Sovereign Immunities Act}

As a result of the dismissal of the Smith case, ${ }^{75}$ recent incidents of terrorism such as the Oklahoma City bombing, ${ }^{76}$ and persuasive lobbying by Senator Frank Lautenberg and the Flatow family, ${ }^{77}$ Congress drastically amended the Foreign Sovereign Immunities Act. By removing the cloak of sovereign immunity for acts of state-sponsored terrorism, and by specifically providing for private rights of action, the 1996 amendments greatly enhance the ability of a private litigant to subject a foreign sovereign to domestic jurisdiction.

The first amendment to the FSIA was enacted as part of the AntiTerrorism and Effective Death Penalty Act of 1996 ("AEDPA"). ${ }^{78}$ This Act amends the FSIA in two distinct ways. First, it provides that nations designated as state sponsors of terrorism are not immune from civil suits in U.S. courts for terrorist acts they commit, or direct to be committed, against American citizens or nationals outside of the foreign state's territory. ${ }^{79}$ This new exemption attempts to rectify the problem the non-commercial tort exception created in cases such as Smith. In order to qualify under AEDPA's exemption, the alleged act of state-sponsored terrorism need not have any territorial nexus to the

${ }^{75}$ See H.R. REP. NO. 105-48, at 2 (1997) (noting that the addition of the statesponsored terrorism exception $[\S 1605(\mathrm{a})(7)]$ was the direct result of the "revelation that the Libyan government assisted in blowing up Pan Am 103 over Lockerbie, Scotland ${ }^{n}$ and the failure of the current FSIA to provide a proper redress); see also John $\mathrm{F}$. Murphy, Foreign Claims, 32 INT'L LAW. 453, 455 (1998) ("The frustrations of the plaintiffs in the Smith case ... provided the political momentum that led to the revisions to the FSIA contained in the [AEDPA].").

${ }_{76}$ See Statement on Signing the Antiterrorism and Effective Death Penalty Act of 1996, 1996 PuB. PAPERS 630 (Apr. 24, 1996) ("After the tragedy in Oklahoma City, I asked Federal law enforcement agencies to reassess their needs and determine which tools would help them meet the new challenge of domestic terrorism. They produced, and I transmitted to the Congress, the 'Antiterrorism Amendments Act of 1995' in May 1995."); see also 141 CONG. REC. H4600 (daily ed. May 9, 1995) (statement of Rep. Fox) (noting that the House proposed amendments to the FSIA in response to the Oklahoma City bombing).

7 See 60 Minutes, supra note 1 (discussing Senator Lautenberg's involvement and the Flatow family's lobbying of Congress for anti-terrorism legislation).

${ }^{78}$ For a thorough examination of the legislative history of the AEDPA, see Roberta Smith, Note, America Tries to Come to Terms with Terrorism: The United Stales Anti-Terrorism and Effective Death Penally Act of 1996 v. British Anti-Terrorism Law and. International Response, 5 CARDOZOJ. INT'L \& COMP. L. 249, 261-77 (1997).

${ }^{79}$ See H.R. REP. NO. 104-383, at 62 (1995) (noting that the amendment would allow "suits in the federal courts against countries responsible for terrorist acts where Americans and/or their loved ones suffer injury or death at the hands of the terrorist states"). For the complete text of AEDPA's amendment to the FSIA, see supra note 8. 
United States. Second, AEDPA amended $\S 1610$ (a) of the FSIA to permit the attachment of property or assets of a foreign state in the United States in order to satisfy a "judgment relat[ed] to a claim for which the foreign state is not immune under section 1605 (a) (7), regardless of whether the property is or was involved with the act upon which the claim is based." 80

While AEDPA's provisions provide that a sovereign will not enjoy immunity from suit where the nation either caused or sponsored death or personal injury in a terrorist attack, there are several important limitations that must be noted. First, only claims for personal injury or death are covered by these amendments. ${ }^{81}$ Any claim for damaged property or economic loss is beyond the scope of this amendment. Second, a litigant may only bring claims against nations that have been designated by the State Department as sponsors of terrorism. ${ }^{82}$ Thus, at the present time, only Cuba, Iraq, Iran, Libya, North Korea, Sudan, and Syria are subject to this amendment. ${ }^{83}$ All other nations, even if they engage in similar activities, presumably retain their sovereign immunity. Finally, even if the foreign state is designated by the State Department as a state sponsor of terrorism, the court will decline to exercise its jurisdiction if the "act occurred in the foreign state against which the claim has been brought and the claimant has not afforded the foreign state a reasonable opportunity to arbitrate the claim, ${ }^{, 84}$ or if neither the claimant nor the victim was a "national of the United States ... when the act upon which the claim is based occurred. ${ }^{255}$

The addition of a state-sponsored terrorism exception to the FSIA represented the first "successful expansion of exceptions to sovereign immunity in 30 years." ${ }^{, 86}$ It was not, however, the final revision. Within

${ }^{80} 28$ U.S.C. $\$ 1610$ (a) (7) (Supp. III 1997).

${ }^{81}$ See id. $\S 1605$ (a)(7) (limiting recovery to cases "in which money damages are sought against a foreign state for personal injury or deatl" (emphasis added)).

${ }^{82}$ See id. $\$ 1605$ (a) (7) (A) (requiring the court to decline to hear a claim under the statute "if the foreign state was not designated as a state sponsor of terrorism under 6(j) of the Export Administration Act of 1979 or section 620A of the Foreign Assistance Act of $1961^{\prime \prime}$ ).

${ }^{83}$ See Defense Federal Acquisition Regulation Supplement: Terrorist Countries, 59 Fed. Reg. 51,130, 51,131 (1994) (to be codified at 48 C.F.R. pt. 252) (proposed Oct. 7, 1994).

28 U.S.C. $\$ 1605(\mathrm{a})(7)(\mathrm{B})$ (i).

${ }^{85}$ Id. $\$ 1605$ (a) (7) (B) (ii). The term "national of the United States" is defined in $\S 1101$ (a) (22) of the Immigration and Nationality Act, 8 U.S.C.A. $\$ 1101$ (West 1999).

${ }^{86}$ Naomi Roht-Arriaza, The Foreign Sovereign Immunities Act and Human Rights Violations: One Step Fonvard, Two Sleps Back?, 16 BERKELEYJ. INT'L L. 71, 82 (1998). 
one year, another act would also alter the evolution of sovereign immunity. Alisa Flatow's tragic death was the catalyst for a second piece of legislation, the Civil Liability for Acts of State Sponsored Terrorism Act. ${ }^{87}$ With the shield of sovereign immunity removed, the Flatow family sought to hold Iran accountable for Alisa's death and impose a substantive sanction against Iran through monetary remuneration. ${ }^{88}$

The Flatow Amendment imposes the possibility of massive civil liability by providing for recovery for non-economic harms, such as solatium damages and pain and suffering, as well as punitive damages against an "official, employee, or agent of a foreign state designated as a state sponsor of terrorism." ${ }^{89}$ As noted by Professors Glannon and Atik, the language of this amendment does not state specifically whether or not the foreign states themselves are subject to liability for violations of $\S 1605$ (a) (7). ${ }^{90}$ Yet, several courts have interpreted this amendment, like the noncommercial tort exception, as establishing joint and several liability that extends to the state itself through the doctrines of respondeat superior and vicarious liability. ${ }^{91}$

${ }^{87} 28$ U.S.C. $\$ 1605$ note (Supp. III 1997) ("Civil Liability for Acts of State Sponsored Terrorism") (citing Foreign Operations, Export Financing, and Related Programs Appropriations Act of 1997, Pub. L. No. 104-208, division A, tit. I, § 101 (c) [tit. $\mathrm{V}, \S 589]$, 110 Stat. 3009-172). For the text of the Flatow Amendment, see supra note 9 (providing liability for state officials who act in their official capacity in sponsoring terrorism).

\& See generally Gerson, supra note 12, at A15 (discussing the potential effect of civil damage awards in curbing terrorist sponsorship).

${ }^{89} 28$ U.S.C. $\$ 1605$ note.

${ }^{90}$ See Joseph W. Glannon \& Jeffrey Atik, Politics and Personal Jurisdiction: Suing State Sponsors of Terrorism Under the 1996 Amendments to the Foreign Sovereign Immunilies Acl, 87 GEO. L.J. 675, 676 n.5 (1999) ("It is not clear whether the foreign state itself is subject to liability under the Act.").

${ }^{91}$ This theory was accepted in Liu $v$. Republic of China, 892 F.2d 1419 (9th Cir. 1989). In this case, the widow of a man killed by an individual acting under orders of Taiwan's Defense Intelligence Bureau brought suit against Taiwan for damages. The Ninth Circuit held that the district court erred in deciding that the foreign sovereign could not be held liable under respondeat superior because the individual's act was not committed within the scope of his employment. See $i d$. at 1434 (holding that the act of state doctrine does not prevent sovereign liability under California's law of respondeat superior). The district court for the Southern District of Florida, in Alejandre v. Republic of Cuba, 996 F. Supp. 1239 (S.D. Fla. 1997), reached the same result with regard to the Flatow Amendment. The court noted that "[i]f plaintiffs prove an agent's liability under this Act, the foreign state employing the agent would also incur liability under the theory of respondeat superior." Id. at 1249 (citing Skeen v. Federative Republic of Brazil, 566 F. Supp. 1414, 1417 (D.D.C. 1983)). 


\section{THE THEORETICAL IMPLICATIONS OF THE 1996 AMENDMENTS}

Part I of this Comment traced the evolution of sovereign immunity from the early manifestations of absolute immunity to the recent amendments to the FSIA. If one were to place this evolution on a continuum, a clear and logical progression would emerge. The transition from absolute to restrictive immunity was gradual and reflected several practical and international concerns. ${ }^{92}$ Furthermore, uncodified acceptance of the restrictive theory proved unworkable over time and gradually persuaded Congress to enact the FSIA, which provided limited and narrowly-drawn exceptions to the presumption of immunity. ${ }^{93}$

Despite this gradual and methodical progression, the FSIA has undergone a drastic transformation within the past three years. Notwithstanding the recent amendments' laudable intentions, from a theoretical perspective, these acts represent an unjustified deviation from the gradual evolution of sovereign immunity. When Congress enacted the FSIA, it did so in a way that "reflect[ed] both the political sensitivity and the legal complexity in the area of foreign sovereign immunity. ${ }^{94}$ Although the amendments attempt to rectify the problems that plagued private suits for acts of terrorism, the new legislation does not reflect the same thoughtful inquiry that preceded the FSIA. By removing the jurisdictional nexus requirement, ignoring due process concerns, and creating additional substantive causes of actions, the 1996 amendments represent an unwarranted departure from traditional international and American jurisprudence regarding sovereign immunity.

\section{A. The Nexus Requirement and Jurisdiction}

Public international law traditionally recognizes three types of jurisdiction. ${ }^{95}$ First, jurisdiction to prescribe (prescriptive jurisdiction) encompasses "the authority of a state to make its substantive law appli-

${ }_{92}$ See supra Part I.B (describing Jack Tate's reasoning for the transition from absolute to restrictive immunity and the gradual acceptance of restrictive immunity by the United States in actions brought against it).

${ }^{93}$ See supra Part I.C (arguing that the adoption of the FSIA was a deliberate attempt to codify the doctrine of restrictive immunity with narrow and circumscribed exceptions).

${ }_{94}$ Borek Statement, supra note 49 , at 12.

${ }^{95}$ See RESTATEMENT, supra note 44, $\$ 401$ (1986) (providing for three types of jurisdiction: jurisdiction to prescribe, jurisdiction to adjudicate, and jurisdiction to enforce). 
cable to persons or activities. ${ }^{\text {} 96}$ Second, jurisdiction to adjudicate (adjudicatory jurisdiction) provides "the authority of a state to subject particular persons or things to its judicial process. ${ }^{, 97}$ Finally, jurisdiction to enforce (enforcement jurisdiction) authorizes "a state to use the resources of government to induce or compel compliance with its law. ${ }^{~}{ }^{8}$ In analyzing Congress's ability to enact the recent amendments to the FSIA, it is necessary to examine Congress's basis of prescriptive jurisdiction.

\section{Territorial Jurisdiction and the Foreign Sovereign Immunities Act}

Although international law recognizes five bases for prescribing jurisdiction ${ }^{99}$-territory, ${ }^{100}$ nationality, ${ }^{101}$ the protective principle, ${ }^{102}$ passive personality, ${ }^{103}$ and the universal principle ${ }^{104}$-Congress purposefully employed territorial jurisdiction in almost all the exceptions to the FSIA, as originally enacted. ${ }^{105}$ The decision to limit the FSIA's

${ }^{96} I d . \mathrm{pt} . \mathrm{IV}$, introductory note, at 231.

${ }^{97}$ Id.

${ }^{98} I d$.

97 See CARTER \& TRIMBLE, supra note 25, at 728 (enunciating the traditional bases of prescriptive jurisdiction).

${ }^{100}$ Territorial jurisdiction is the exclusive authority of a state to regulate within its territory. See id. at 737 (defining this theory as providing each state the exclusive authority to regulate in its territory and no authority to regulate outside its territory).

${ }^{101}$ Nationality jurisdiction is commonly referred to as " $[t]$ he right of a state to regulate the conduct of its citizens or nationals anywhere in the world." Id. at 760.

${ }^{102}$ The protective principle is based upon the assumption that "a state is entitled to protect its security by means of the exercise of its jurisdiction." D.W. Bowett, Jurisdiction: Changing Patterns of Authority over Activities and Resources, in INTERNATIONAL LAW: GLASSIC AND CONTEMPORARY READINGS 207, 214 (Charlotte Ku \& Paul F. Diehl eds., 1998). The principle application of this jurisdiction is in respect to "political offenses such as espionage, sedition, counterfeiting of currency, perjury in relation to official documents ... or attacks against embassies and consulates abroad." Id.

${ }^{103}$ The passive personality basis of jurisdiction "asserts that a state may apply lawparticularly criminal law-to an act committed outside its territory by a person not its national where the victim of the act was its national." RESTATEMENT, supra note 44, $\$ 402 \mathrm{cmt}$. $\mathrm{g}$.

${ }^{104}$ Universal jurisdiction provides that " $[a]$ state has jurisdiction to define and prescribe punishment for certain offenses recognized by the community of nations as of universal concern." Id. \$ 404. As Rosalyn Higgins notes, "[c]ontrary to popular belief, terrorism is not subject to universal jurisdiction-some degree of connection with the event is required." Rosalyn Higgins, The General International Law of Terrorism, in TERRORISM AND INTERNATIONAL LAW 13, 24 (Rosalyn Higgins \& Maurice Flory eds., 1997).

${ }^{105}$ The commercial activity exception requires that the action is based upon a commercial activity carried on in the United States; a related act performed in the United States; or a related act, carried on elsewhere, that has a direct effect on the 
exceptions to actions occurring in, or having a direct effect on, the United States was the result of careful deliberation by Congress and the executive branch ${ }^{106}$ which wished to ensure that the exceptions to the presumption of sovereign immunity would not have an inequitable extraterritorial application. ${ }^{107}$

Throughout U.S. history there has been a strong presumption against extraterritorial application of U.S. laws. ${ }^{108}$ Justice Holmes, in American Banana Co. v. United Fruit Co., noted that extraterritorial application of law "not only would be unjust, but would be an interference with the authority of another sovereign, contrary to the comity of nations, which the other state concerned justly might resent. . . 'All legislation is prima facie territorial.", 109 To Justice Holmes, "it was inconceivable that an act of Congress would apply outside the territory of the United States." ${ }^{\text {"10 }}$ Ever since American Banana, territoriality has been regarded as "a firmly established concomitant of the concept of state sovereignty, and...the most fundamental form of jurisdiction." ${ }^{111}$ Although the courts, Congress, and administrative agencies

United States. See 28 U.S.C. $\$ 1605$ (a) (2) (1994) (stating a general exception to the jurisdictional immunity of a foreign state). The expropriation exception removes sovereign immunity where "rights in property taken in violation of international law are in issue and that property ... is present in the United States." Id. $\S 1605(a)(3)$. Furthermore, $\S 1605$ (a) (4) withdraws immunity where "rights in property in the United States acquired by succession or gift or rights in immovable property situated in the United States are in issue." Id. $\$ 1605$ (a) (4).

${ }^{106}$ See Borek Statement, supra note 49, at 12 ("In crafting the FSIA, Congress and the Executive Branch created a carefully balanced structure that provides immunity in some cases and exceptions to immunity in others. The statute reflects not only a recognition of the foreign relations interests involved but also a fundamental concern for international law and practice.").

${ }^{107}$ See The Foreign Sovereign Immunities Act: Hearings on S. 825 Before the Subcomm. on Courts and Admin. Practice of the Senate Comm. on the Judiciary, 103d Cong. 82 (1996) (statement of Abraham D. Sofaer, George P. Shultz Distinguished Scholar and Senior Fellow, Hoover Institution, Stanford University) [hereinafter Sofaer Statement] (arguing that requiring a U.S. nexus would prevent an "extra-territorial extension of the jurisdiction of our courts to adjudicate that is not warranted by international law"); see also supra notes 62-64 and accompanying text (discussing the reluctance of federal courts to extend the scope of the noncommercial tort exception to activities outside the United States).

${ }^{103}$ See CARTER \& TRIMBLE, supra note 25 , at 738 ("This tendency ... to apply U.S. law extraterritorially has been sharply resisted by foreign courts, governments, and scholars, and continues to generate controversy.").

${ }^{109} 213$ U.S. 347, 356-57 (1909) (internal citations omitted), overruled by Continental Ore Co. v. Union Carbide \& Carbon Corp., 370 U.S. 690, 704-05 (1962) (observing that anti-competitive action on foreign soil that affects U.S. commerce is subject to U.S. antitrust law).

${ }^{110}$ CARTER \& TRIMBLE, supra note 25, at 737.

"' David Freestone, International Cooperation Against Terrorism and the Development of 
have, over time, chipped away at this absolute bar to extraterritorial application of U.S. laws, ${ }^{112}$ territorial jurisdiction has always retained its fundamental quality. ${ }^{113}$ Requiring a territorial nexus to the United States reaffirmed territorial jurisdiction as one of the principle bases of jurisdiction ${ }^{114}$ and ensured that the FSIA would not have an unreasonable extraterritorial effect.

Territorial jurisdiction also served as the basis for several of the FSIA's exceptions to sovereign immunity since the drafters were cognizant of the role the FSIA would play in the development of international law. ${ }^{115}$ As the sole means of exercising jurisdiction over a foreign state, it was of the utmost importance to base the FSIA upon a solid jurisdiction basis. ${ }^{116}$ Since territorial jurisdiction is regarded as the most fundamental basis of jurisdiction ${ }^{\text {I17 }}$ and "had a substantial basis in international practice, ${ }^{\text {,118 }}$ it was capable of providing such a framework. Most European states, for example, employ territorial jurisdiction in comparable statutes. ${ }^{119}$ Furthermore, multilateral conventions, such as the European Convention on State Immunity, deny immunity "if the facts which occasioned the injury or damage oc-

International Law Principles of Jurisdiction, in TERRORISM AND INTERNATIONAL LAW, supra note 104 , at 43.

12 See CARTER \& TRIMBLE, supra note 25, at 738 (noting the tendency of courts and law enforcement agencies to apply laws extraterritorially when foreign acts have a substantial effect on the United States).

${ }^{113}$ See Bowett, supra note 102, at 210 ("[T] he proposition that a state has the right to regulate conduct within its territory would be regarded as axiomatic."). But see Gary B. Born, A Reappraisal of the Exiraterritorial Reach of U.S. Law, 24 LAW \& POL'Y INT'L BUS. 1,1 (1992) (arguing that the "rationale for the territoriality presumption has become obsolete and that the presumption should be abandoned").

${ }^{114}$ See RESTATEMENT, supra note 44, ch. 1, introductory note (arguing that territoriality remains a principal basis of jurisdiction to prescribe).

${ }^{115}$ See Borek Statement, supra note 49 , at 14 ("Consistency of the FSIA with established international practice is important. If we deviate from that practice and assert jurisdiction over foreign states for acts that are generally perceived by the international community as falling within the scope of immunity, this would tend to erode the credibility of the FSIA.").

${ }^{116}$ See supra Part I.C (describing the enactment of the FSIA).

117 See CARTER \& TRIMBLE, supra note 25, at 729 ("'It is an essential attribute of the sovereignty of this realm, as of all sovereign of independent States, that it should possess jurisdiction over all persons and things within its territorial limits and in all causes civil and criminal arising within these limits.") (excerpting from J. STARKE, INIRODUCTION TO INTERNATIONAL LAW 193 (9th ed. 1984)).

${ }^{118}$ Borek Statement, supra note 49 , at 13.

119 See United Kingdom: State Immunity Act, 1978, ch. 33 (Eng.), reprinted in 17 I.L.M. 1123 (1978) (providing general immunity from jurisdiction but making an exception for a tort committed in the United Kingdom or a commercial transaction performed there); see also Borek Statemenh supra note 49, at 13 (noting that the sovereign immunity statute of Australia also provides territorial jurisdiction). 
curred in the territory of the State of the forum, and if the author of the injury of damage was present in that territory at the time when those facts occurred.",20

By not requiring any territorial nexus to the United States, however, the state-sponsored terrorism exception drastically unravels what had been so carefully constructed. In enacting the terrorism exception, Congress not only deviated from traditional American jurisprudence and international practice, ${ }^{121}$ but it also replaced the traditional notion of territorial jurisdiction with the most controversial and the least justifiable jurisdictional predicate-the passive personality principle. $^{122}$

\section{The Passive Personality Principle and the 1996 Amendments}

The passive personality doctrine maintains that a nation can assert jurisdiction over "non-nationals for crimes committed against its nationals outside of its territory, at least where the state has a particularly strong interest in the crime." for establishing jurisdiction under this doctrine is the nationality of the victim. Focusing on nationality rather than on the location of the act demonstrates that the passive personality principle's main concern is the "crime's effect, rather than where it occurs."124 Passive personality jurisdiction is embodied in AEDPA's state-sponsored terrorism ex-

${ }^{120}$ Council of Europe: European Convention on State Immunity and Additional Protocol, done May 16, 1972, 11 I.L.M. 470, 473 (1972) (reproduced from the text provided by the Council of Europe); see also Bowett, supra note 102, at 210 (acknowledging that the European Convention on the Suppression of Terrorism also utilizes territorial jurisdiction).

${ }^{121}$ See Borek Statement, supra note 49, at 14 ("Not only does such a provision extend well beyond the reach of our existing statute, but it also diverges significantly from the general practice of states....").

122 See IAN BRownlie, Princtiples of Public International Law 303 (4th ed. 1990) (arguing that the passive personality principle "is the least justifiable [of all existing jurisdictional bases], as a general principle"); see also Freestone, supra note 111, at 44-45 (observing that passive personality jurisdiction "has traditionally been regarded by commentators as at the fringes of customary international law, and Anglo-Saxon writers have been particularly vocal in condemning its legality"); John G. McCarthy, Note, The Passive Personality Principle and Its Use in Combating Intermational Terrorism, 13 FORDHAM INT'L L.J. 298, 301 (1989-1990) ("The passive personality principle is the most controversial of the five accepted bases of jurisdiction in international law.").

${ }^{129}$ United States v. Yunis, 924 F.2d 1086, 1091 (D.C. Cir. 1991). It has been argued that passive personality jurisdiction is based not just upon a nation's interest, but also flows from a nation's duty "to protect its nationals abroad." McCarthy, supra note 122, at 301.

${ }^{124}$ McCarthy, supra note 122, at 301. 
ception through 28 U.S.C. $\S 1605$ (a)(7)(B) (ii). This subsection forbids actions pursuant to the terrorism exception where neither the "claimant nor the victim was a national of the United States ... when the act upon which the claim is based occurred."125

The passive personality doctrine, "always uncertain and never really consolidated in general international practice, ${ }^{\$ 26}$ has, since its inception, been a source of conflict. The main point of contention is that "subject[ing] an individual to the laws of a country with which the individual's only connection is the victim's nationality" ${ }^{\text {"27 }}$ is an abusive assertion of jurisdiction. From early cases such as the Cutting Case, ${ }^{128}$ to the Permanent Court of International Justice's ("PCIJ") discussion of passive personality in The Case of the Steamship "Lotus, ",29 there has always been great resistance by the international community to judicial validation of the exercise of passive personality jurisdiction.

Although some support for the use of the passive personality doctrine may be found in U.S. foreign policy legislation ${ }^{130}$ and case law,

${ }^{125} 28$ U.S.C. § I605(a) (7) (B) (ii) (Supp. III 1997).

${ }^{126}$ Higgins, supra note 104, at 24.

${ }^{127}$ McCarthy, supra note 122, at 302.

${ }^{123}$ In the Culting Case, a U.S. citizen published an allegedly defamatory article in a Texas newspaper. While in Mexico he was arrested and charged with criminal libel. The Mexican government asserted jurisdiction based upon the passive personality jurisdiction. The United States vigorously objected to this exercise of jurisdiction. Unfortunately, the conflict ended without the issue of passive personality jurisdiction being resolved. See The Cutting Case (Bravos district court 1886), translated in THE LAW OF NATIONS (Herbert W. Briggs ed., 2d ed. 1952); see also BROWNLIE, supra note 122, at 303 (describing the jurisdictional controversy); McCarthy, supra note 122, at 302-03 (summarizing the facts of the case).

${ }^{120}$ (Fr. v. Turk.), 1927 P.C.I.J. (ser. A) No. 10, at 23. This case involved a collision between a French steamer and a Turkish boat in international waters. The Turkish vessel sank, killing many of the passengers and crew. As a result, the Turkish government brought involuntary manslaughter charges against the officers on watch aboard the French steamer. The French government asked the PCT to determine whether or not the Turkish government, by bringing charges against the French citizens solely on the basis of the victims' nationality, violated international law. Although the PCIJ was divided (6-6), the President cast the definitive vote to hold that the Turkish government had not violated international law. See BROWNLIE, supra note 122, at 301-02 ("By the casting vote of the President ... the court decided that Turkey had not acted in conflict with the principles of international law by exercising criminal jurisdiction."). The significance of this case, as argued by the dissenting judges, is that the extraterritorial application of a nation's laws to cover actions committed by foreigners against "nationals" violated established norms of international law. See McCarthy, supra note 122, at 304 ("All of the dissenting judges rejected the passive personality principle because it did not conform with international law.").

${ }^{130}$ For example, the passive personality principle did serve as the basis for jurisdiction in the Omnibus Diplomatic Security and Anti-Terrorism Act of 1986, Pub. L. No. 99-399, 100 Stat. 855. See Smith, supra note 78, at 256 ("The Omnibus Diplomatic Se- 
the application of this doctrine has been limited to narrowly-defined situations, and the doctrine has never served as the sole basis for jurisdiction. For example, United States v. Benitez ${ }^{131}$ is frequently cited in arguments supporting the exercise of jurisdiction based on the passive personality principle. In that case, Armando Benitez, a Colombian citizen, was convicted in federal court on charges of conspiring to murder Drug Enforcement Administration ("DEA") agents engaged in the performance of their official duties and of assaulting and robbing two DEA agents with a deadly weapon while they were performing official duties. ${ }^{132}$ Upon review, the court rejected the defendant's argument that it improperly exercised its jurisdiction and held that jurisdiction existed under both the protective and passive personality principles. $^{133}$

Although passive personality provided thus one basis of jurisdiction, it was not the sole basis. In fact, the court primarily predicated its finding of jurisdiction upon the protective principle, and this basis should be regarded as the more substantial of the two. Integral to the court's reasoning was the fact that assaulting government agents while performing their official duties has a "potentially adverse effect upon the security or governmental functions of the nation." ${ }^{134}$ The court, without citing any authority, validated the use of passive personality as a secondary basis of jurisdiction because the victims also were nationals of the United States. ${ }^{135}$ The court noted, however, that the victims were not simply Americans citizens-they were American citizens "who [were] also United States government agents." 136 Thus, the victims' occupations, rather than their nationality, served as the true basis of jurisdiction, and the use of passive personality in this case may therefore be conceived of as simply an extension of the protective

curity and Anti-Terrorism Act of 1986 extended United States extraterritorial jurisdiction to foreign nationals involved in acts which injured United States citizens." (citation omitted)). Yet, it must be recognized that this Act has been severely criticized as being "too broad and too vague." Id. at 257 (citing Patrick L. Donnelly, Note, Extraterrilorial Jurisdiction over Acts of Terrorism Committed Abroad: Omnibus Diplomatic Security and Anti-Terrorism Act of 1986, 72 CORNELL L. REV. 599 (1987)). Consequently, this Act cannot serve as an affirmative example of the acceptance of the passive personality principle.

131 741 F.2d 1312 (11th Cir. 1984).

132 See id. at 1313 (describing the nature of Benitez's convictions).

${ }^{139}$ See id. at 1316 (noting that there was no doubt that jurisdiction existed under the protective and passive personality principles).

${ }_{134} I d$.

${ }^{135}$ See id. ("[T] he nationality of the victims ... . clearly supports jurisdiction.").

${ }^{136} \mathrm{Id}$. 
principle. ${ }^{137}$ Thus, one cannot extrapolate from the court's use of the passive personality doctrine as a secondary basis for jurisdiction that the doctrine is substantially legitimized by U.S. case law. ${ }^{139}$

Although the passive personality principle has been incorporated into several multilateral statutes, these statutes, like the aforementioned judicial precedents, are predicated only in part upon the doctrine. The International Convention Against the Taking of Hostages $^{139}$ provides a solid example of the inferior status of the passive personality principle in international law. This convention, which condemns the act of hostage taking, requires all signatories to establish jurisdiction over any act prohibited by the convention. ${ }^{140}$ While the state in which the act occurred must establish its jurisdiction over such offenses, ${ }^{141}$ the state seeking to assert jurisdiction pursuant to the passive personality doctrine does not have any affirmative obligation. Rather, in order to assert such jurisdiction, it must consider such an exercise of jurisdiction "appropriate."142 In other words, those countries that can assert territorial jurisdiction must do so. This is an affirmative obligation on all signatories. Yet, those countries that can only assert jurisdiction on the basis of passive personality can only do

${ }^{197}$ The protective principle was enacted for just this type of scenario. See supra note 102 (discussing protective jurisdiction and its bases).

${ }^{13 s}$ United States v. Yunis, 681 F. Supp. 896 (D.D.C. 1988) is also cited as authoritative support for the passive personality principle. Yet here too, it must be noted that passive personality jurisdiction was not the sole basis of jurisdiction. See id. at 903 (" $[T]$ he Universal and Passive Personality principles, together, provide ample grounds for this court to assert jurisdiction over [the defendant]."). Furthermore, the court even acknowledged that upholding jurisdiction on the basis of nationality went beyond the norms of international law. See also United States v. Columba-Colella, 604 F.2d 356, 360 (5th Cir. 1979) (stating that the mere fact that "an act affects the citizen of a state is not a sufficient basis for that state to assert jurisdiction over the act" and that "Congress would not be competent to attach criminal sanctions to the murder of an American by a foreign national in a foreign country, even if the victim returned home and succumbed to his injuries").

${ }^{139}$ Drafting of an International Convention Against the Taking of Hostages, U.N. GAOR 6th Comm., 34th Sess., Annex, Agenda Item 113, U.N. Doc. A/C.6/34/L.23 (prov. ed. 1979), reprinted in 18 I.L.M. 1456 (1979).

${ }^{140}$ Article 5(1) provides that "[e]ach State Party shall take such measures as may be necessary to establish its jurisdiction over any of the offenses set forth in article 1 [relating to hostage taking] ...." Id. at 1458.

${ }^{111}$ See id. (discussing, in art. $5(1)(a)$, the mandatory assertion of jurisdiction over those who commit a crime mentioned in article 1 within a State Party's territory).

${ }^{112}$ Id. David Freestone clarifies the meaning of this article by stating that it is not up to the state wishing to seek jurisdiction under the passive personality principle to consider such action appropriate. Rather, the article confers discretion to proceed with passive personality jurisdiction only to the state with primary jurisdiction (i.e. territorial). See Freestone, supra note 111, at 53 (clarifying the article's meaning). 
so if the exercise of jurisdiction is appropriate. Consequently, the established case law and international precedents clearly demonstrate that prescribing jurisdiction solely on the basis of the passive personality doctrine represents a significant deviation from dominant trends in American and international jurisprudence.

Even assuming, arguendo, that the passive personality doctrine is an appropriate basis of prescriptive jurisdiction in this scenario, the use of this principle is necessarily limited by an international rule of reasonableness ${ }^{143}$ and notions of comity. ${ }^{144}$ This concept of reasonableness is reflected in section 403 of the Restatement (Third) of the Foreign Relations Law of the United States, which provides that in assessing the reasonableness of the exercise of jurisdiction the following factors, among others, must enter the calculus: the link of the activity to the regulating state; the character of the activity to be regulated; the connections-such as nationality, residence, or economic activity-between the regulating state and the person principally responsible for the activity to be regulated; the importance of the regulation to the international political, legal or economic system; and the extent to which another state may have an interest in regulating the activity. ${ }^{145}$

Predicating passive personality jurisdiction solely upon the victim's nationality, while ignoring all of these other factors, demonstrates that the focus of the terrorism exception is far too myopic. Combating international terrorism is an effort which involves a multitude of players whose interests should not be sacrificed or overlooked. Not only do foreign states in which these torts are committed have a significant interest in bringing such perpetrators to justice, but these states may provide a more appropriate forum for redress. ${ }^{146}$ When we

${ }^{143}$ See CARTER \& TRIMBIE, supra note 25, at 738-40 (quoting RESTATEMENT, supra note $44, \S 403$ and commenting thereupon); see also RESTATEMENT, supra note $44, \S$ $403 \mathrm{cmt}$. a ("The principle that an otherwise valid exercise of jurisdiction ... is nonetheless unlawful if it is unreasonable is established in United States law, and has emerged as a principle of international law as well.").

${ }^{14}$ See McCarthy, supra note 122, at 308 (acknowledging that notions of comity have limited the application of the passive personality principle which has, in turn, led to greater acceptance of this basis of prescriptive jurisdiction); see also CARTER \& TRIMBLE, supra note 25 , at 737-38 (defining comity as "the recognition which one nation allows within its territory to the legislative, executive, or judicial acts of another nation, having due regard both to international duty and convenience, and to the rights of its own citizens or of other persons who are under the protection of its laws'" (quoting Hilton v. Guyot, 159 U.S. 113, 163-64 (1895))).

${ }^{115}$ See RESTATEMENT, supra note $44, \S 403$ (2)(a)-(h) (listing these and other similar factors to be considered).

${ }_{146}$ See Sofaer Statement, supra note 107, at 83 ("[W] here the domestic courts of the foreign state in which a covered injury occurs provide an adequate and affecting rem- 
remove the territorial nexus requirement in the state-sponsored terrorism exception, and prescribe jurisdiction solely upon the basis of the passive personality principle, we simply fail to adequately "balance the interests of the country whose national has been victimized against that of the country with territoriality jurisdiction." 147

\section{B. The Nexus Requirement and Due Process}

As Professor Mary Kay Kane has noted, "whether the Republic of France can be sued is very different from the question of where France may be sued." ${ }^{148}$ While the former is a question of prescriptive jurisdiction and sovereign immunity, the latter is a question of adjudicative jurisdiction. Although "[i]nternational law places very few constraints on the exercise of adjudicatory jurisdiction, ${ }^{149}$ its exercise is clearly limited by notions of due process in the United States. ${ }^{150}$

From a historical perspective, American jurisprudence has always assumed that foreign states possess due process rights. ${ }^{151}$ Courts have typically provided foreign states with such rights because when a statedefendant acts in its non-official capacity (i.e., when the cloak of sovereign immunity is removed), it stands before the court like any other foreign non-governmental defendant. ${ }^{152}$ Given that due process rights are afforded to foreign corporations ${ }^{153}$ and to foreign private per-

edy, the aggreived person ... must pursue that remedy."). It is interesting to note that the state-sponsored terrorism exception, while ignoring the concerns of the state in which the activity occurs, does recognize the interests of the foreign state against whom suit is brought and even forbids such suits unless recourse to the judicial processes of the foreign state has proven futile. See 28 U.S.C. $\$ 1605$ (a)(7) (B) (i) (Supp. III 1997) (stating that the foreign state must be afforded "a reasonable opportunity to arbitrate the claim").

147 McCarthy, supra note 122, at 308.

${ }^{14}$ Mary Kay Kane, Suing Foreign Sovereigns: A Procedural Compass, 34 STAN. L. REV. 385, 396 (1982).

${ }^{149}$ MacKusick, supra note 42 , at 761.

${ }^{150}$ See RESTATEMENT, supra note $44, \$ 453 \mathrm{cmt}$ c ("The exercise of jurisdiction by courts in the United States is subject to the due process requirements of the Fifth and Fourteenth Amendments.").

${ }^{151}$ See Victoria A. Carter, God Save the King: Unconstitutional Assertions of Personal Jurisdiction over Foreign States in U.S. Courts, 82 VA. L. REV. 357, 361 (1996) ("The FSIA's legislative history makes clear that Congress drafted this statute with [the assumption that foreign states would enjoy due process rights] in mind.").

${ }^{132}$ See id. at 360 ("' $[W]$ hen a government becomes a partner in any trading company, it devests [sic] itself ... of its sovereign character, and takes that of a private citizen.'" (quoting Bank of the United States v. Planters' Bank of Georgia, 22 U.S. (9 Wheat.) 904, 907 (1824))).

${ }^{159}$ See Asahi Metal Indus. Co. v. Superior Court of Cal., 480 U.S. 102, 113 (1987) (holding that the Due Process Clause prevents a state court from exercising personal 
sons, ${ }^{154}$ logic dictates that a foreign state, stripped of its immunity, should be entitled to the same protections. Consequently, in order to assert a claim against a foreign sovereign nation under the FSIA, due process dictates that the foreign state must have the requisite minimum contacts as required by International Shoe Co. v. Washington. ${ }^{155}$

Texas Trading $\mathcal{E}^{2}$ Milling Corp. v. Federal Republic of Nigeria ${ }^{156}$ is frequently cited as the "seminal case" ${ }^{\text {p157 }}$ providing such protection. In this breach of contract action filed pursuant to the FSIA, the Second Circuit specifically raised the question of whether or not a foreign state is afforded constitutional due process rights and answered this question affirmatively. ${ }^{158}$ Judge Kaufmann, writing for the court, held that "each finding of personal jurisdiction under the FSIA requires ... a due process scrutiny of the court's power to exercise its authority over a particular defendant. ${ }^{\text {159 }}$ A due process scrutiny involves a two-step inquiry: (1) whether the FSIA authorizes jurisdiction over the foreign sovereign; and (2) whether the sovereign nation's contacts with the United States are sufficient to support the exercise of jurisdiction. ${ }^{160}$

jurisdiction over a foreign corporation except under circumstances defined in International Shoe Co. v. Washington, 326 U.S. 310 (1945)).

${ }^{154}$ United States v. Pink, 315 U.S. 203, 228 (1942) ("[A]liens as well as citizens are entitled to the protection of the Fifth Amendment." (citing Russian Volunteer Fleet $v$. United States, 282 U.S. 481, 491-92 (1931))).

${ }^{155} 326$ U.S. 310 (1945). International Shoe requires that "in order to subject a defendant to a judgment in personam... [the defendant must] have certain minimum contacts with [the territory of the forum] such that the maintenance of the suit does not offend "traditional notions of fair play and substantial justice." Id. at 316 (citation omitted); see also RESTATEMENT, supra note $44, \$ 453 \mathrm{cmt}$. c ("Due process requires that for a state to adjudicate claims against a defendant, the defendant must have at least a minimum of contacts with the state."); DAVID EPSTEIN ET AL., INTERNATIONAI LITIGATION: A GUIDE TO JURISDICTION, PRACTICE, AND STRATEGY $\$ 7.14$, at 7-73 to 774 (3d ed. 1998) ("The minimum contacts test of International Shoe Co. v. Washington, and its progeny, are controlling in the determination of whether foreign sovereign defendants are subject to the jurisdiction of United States courts pursuant to section 1330 (b) of the FSIA."); Kane, supra note 148, at 397 ("[W] hen filing suit against a foreign government it is necessary to consider ... whether the assertion of personal jurisdiction would be consistent with the constitutional due process standard set out in $I n$ ternational Shoe v. Washington...." (footnote omitted)).

${ }^{136} 647$ F.2d 300 (2d Cir. 1981).

157 See, e.g., Glannon \& Atik, supra note 90, at 682 (citing Texas Trading as the "seminal case" for reference when determining whether or not a court may exercise personal jurisdiction pursuant to the FSIA provisions and the Due Process Clause).

${ }^{153}$ See Texas Trading, 647 F.2d at 313-14 (affirming a prior judgment wherein due process analysis was applied in a quasi in rem suit against a foreign state).

${ }^{139}$ Id. at 308.

${ }^{160}$ See id. at 312-15; see also El-Hadad v. Embassy of the U.A.E., 69 F. Supp. 2d 69, 77 (D.D.C. 1999) (acknowledging that the second step of the jurisdiction inquiry is neces- 
Although some commentators question "why a foreign sovereign... should be treated as a 'person' under the Due Process Clause," ${ }^{161}$ such a conclusion is entirely consistent with the legislative history of the FSIA. The House Report accompanying the FSIA provides that "[f]or personal jurisdiction to exist under section 1330 (b), the claim must first of all be one ... for which the foreign state is not entitled to immunity., ${ }^{162}$ Thus, the threshold issue is whether or not one of the exemptions from immunity applies. Not only does each exemption create subject matter jurisdiction, however, but the House Report also notes that "each of the immunity provisions in the bill ... requires some connection between the lawsuit and the United States or an express or implied waiver by the foreign state of its immunity. ${ }^{163}$ Thus, each exemption "prescribe [s] the necessary contacts which must exist before our courts can exercise personal jurisdiction." ${ }^{164}$ By requiring minimum contacts with the forum state, the drafters of the FSIA clearly contemplated that foreign states were entitled to due process protection. ${ }^{165}$ Based upon this conclusion, an uncontested progeny of cases has emerged granting due process protection to foreign states. ${ }^{166}$

sary since "Congress may not grant jurisdiction where it would violate the Constitution's Due Process Clause. The Court therefore must also determine whether exercising personal jurisdiction over the defendants is constitutionally permissible").

i6l Glannon \& Atik, supra note 90 , at 683.

${ }^{162}$ H.R. REP. NO. 941487, at 13 (1976), reprinted in 1976 U.S.C.C.A.N. 6604, 6612.

${ }^{169}$ Id.; see also Sarah K. Schano, Note, The Scallered Remains of Sovereign Immunity for Foreign States Afler Republic of Argentina v. Weltover, Inc.-Due Process Protection or Nothing, 27 VAND. J. TRANSNAT'L L. 673, 680 (1994) ("Congress explained that because each immunity provision in the Act requires some connection between the lawsuit in question and the United States, the immunity provisions themselves prescribe the necessary contacts that must exist before a United States court can exercise jurisdiction over a foreign state.").

${ }^{164}$ H.R. REP. No. 94-1487, at 13 (1976), reprinted in 1976 U.S.C.C.A.N. 6604, 6612.

${ }^{165}$ See Carter, supra note 151, at 363 ("This nexus requirement usually ensures that assertions of personal jurisdiction under the FSIA satisfy due process requirements."); see also Verlinden B.V.v. Central Bank ofNig., 461 U.S. 480, 490 (1983) (discussing the "substantial contacts" restrictions in the FSIA that effectively limit U.S. courts' jurisdiction).

${ }^{166}$ See, e.g., Gregorian v. Izvestia, 871 F.2d 1515, 1529 (9th Cir. 1989) (applying Texas Trading due process analysis); Thos. P. Gonzales Corp. v. Consejo Nacional de Produccion de Costa Rica, 614 F.2d 1247, 1250-55 (9th Cir. 1980) (applying a due process analysis to a Costa Rican defendant); Petrol Shipping Corp. v. Kingdom of Greece, 360 F.2d 103, 107 (2d Cir. 1966) (applying service of process requirement); Victory Transport, Inc. v. Comisaria General de Abastecimientos y Transportes, 336 F.2d 354, 364 (2d Cir. 1964) (same); Drexel Burnhan Lambert Group, Inc. v. Committee of Receivers, 810 F. Supp. 1375, 1388 (S.D.N.Y. 1993) (applying constitutional due process requirements to personal jurisdiction analysis under FSIA), rev'd on other grounds, 12 F.3d 317 (2d Cir. 1993); Walpex Trading Co. v. Yacimientos Petroliferos Fiscales Boli- 
Despite this line of authority, Republic of Argentina $v$. Weltover, Inc. ${ }^{167}$ reopened the question of whether or not a foreign state is a person within the meaning of the Fifth Amendment. Justice Scalia, writing for the court, "[a]ssum [ed], without deciding, that a foreign state is a 'person' for purposes of the Due Process Clause." ${ }^{168}$ Yet, Scalia's citation of South Carolina v. Katzenbach ${ }^{169}$ with the parenthetical that "States of the Union are not 'persons' for purposes of the Due Process Clause, ${ }^{\text {"170 }}$ suggests that if the question of whether or not a foreign state is a person within the meaning of the Due Process Clause were specifically presented to the Supreme Court, the holding in Katzenbach would compel the Court to conclude that the answer is no. ${ }^{171}$

Even if, as some commentators have argued, the Constitution does not require courts to provide due process protection to foreign states as defendants, ${ }^{172}$ the inquiry does not end here. The legislative history of the FSIA clearly reveals that it was the specific intent of the drafters to provide such protection by prescribing the minimum contacts necessary for each exception. ${ }^{173}$ The state-sponsored terrorism exception, by removing the territorial nexus and replacing it with the passive personality doctrine's nationality requirement, drastically undermines the due process concerns Congress specifically preserved in enacting the FSIA.

vanos, 712 F. Supp. 383, 390 (S.D.N.Y. 1989) (granting due process protection under FSIA pursuant to Texas Trading); Chicago Bridge \& Iron Co. v. Islamic Republic of Iran, 506 F. Supp. 981, 988 (N.D. Ill. 1980) (applying the International Shoe personal jurisdiction analysis).

${ }^{167} 504$ U.S. 607 (1992).

${ }^{16 s} I d$. at 619.

${ }^{169} 383$ U.S. 301 (1966).

170 Wellover, 504 U.S. at 619 (citing Katzenbach, 383 U.S. at 323-24),

${ }^{171}$ See Glannon \& Atik, supra note 90 , at 680 (concluding that the Court may be inviting reconsideration of the status of foreign states by virtue of its reference to Katzenbach). But see Schano, supra note 163, at 713-17 (concluding that, despite Wellover, compliance with principles of international law and practical considerations compel American courts to provide due process protection to foreign states with respect to a determination of jurisdiction). Other commentators also have argued that Katzenbach does not necessarily compel the conclusion that foreign states are not persons for purposes of the Due Process Clause because of the disparate circumstances. While South Carolina invoked the Due Process Clause in Katzenbach as a plaintiff seeking to invalidate an act of Congress, foreign states, as defendants, invoke the clause merely "to defend against personal jurisdiction ... as unwilling defendants." Carter, supra note 151, at 362. Furthermore, South Carolina did not invoke the Due Process Clause "to avoid litigating matters with little or no connection with the United States." Id.

${ }^{172}$ See Glannon \& Atik, supra note 90, at 688-92 (arguing that history, original intent, and application of International Shoe inevitably lead to the conclusion that the Due Process Clause protects persons, not states).

${ }^{173}$ See supra notes $156-65$ and accompanying text. 
As Professor Kane noted, the goal of the FSIA was to "promote a uniform body of law so that foreign state defendants, as well as private plaintiffs, can predict their exposure to suit and act accordingly." ${ }^{174}$ The mere nationality of the victim, which might not even be known to the offending nation, however, cannot possibly provide the minimum contacts necessary to sustain personal jurisdiction. Furthermore, one may assert the passive personality principle even where the target's nationality does not serve as the basis of the attack. ${ }^{175}$ Therefore, subjecting foreign nations to suit in the United States for acts of terrorism that do not target American citizens cannot possibly comply with international notions of fairness and comity.

The effect of removing the territorial nexus and replacing it with passive personality jurisdiction on the provision of due process rights should, as Professors Glannon and Atik noted, "have given pause to the drafters of the 1996 amendments to the FSIA."176 Yet, due process concerns were not even mentioned in the legislative history of the amendments. ${ }^{177}$ Clearly, Congress did not dedicate the same attention to this issue while enacting the 1996 amendments as it did when enacting the FSIA. By failing to "keep in mind the fundamental interests that [the FSIA] is designed to advance and the careful balances reflected in that law," ${ }^{178}$ these recent amendments represent a drastic departure from traditional sovereign immunity jurisprudence.

\section{Designating State Sponsors of Terrorism and Political Concerns}

One of the most important goals of the FSIA was to remove the unpredictable political element from the decision regarding exemptions of sovereign immunity. ${ }^{179}$ Prior to the enactment of the FSIA, the executive branch, acting only upon the initiative of a foreign na-

174 Kane, supra note 148 , at 403.

${ }^{175}$ See United States v. Yunis, 924 F.2d 1086, 1091 (D.C. Cir. 1991) (determining that a terrorist need not target nationals of the state asserting jurisdiction in order to subject himself to passive personality jurisdiction).

${ }^{176}$ Glannon \& Atik, supra note 90 , at 685 . These commentators also suggested that by ignoring the precedential authority of cases applying due process concerns to foreign states, these recent amendments are "on a collision course" with established judicial authority. Id. at 679 .

17 See id. at 685 ("A diligent search of the background documents revealed virtually no reference to any constitutional due process problem in extending federal jurisdiction to such cases.").

${ }^{178}$ Borek Siatement, supra note 49, at 12-13.

179 See supra Part I.B (demonstrating that decisions regarding sovereign immunity prior to the enactment of the FSIA were politically motivated and unreliable). 
tion, decided whether or not to waive sovereign immunity. This delegation of power, however, resulted in politically motivated, inconsistent results. ${ }^{180}$ As a result, Congress decided that allowing the judiciary, which would act on a nonpartisan basis, to make such determinations would greatly enhance the predictability and uniformity of U.S. sovereign immunity jurisprudence. ${ }^{181}$

The state-sponsored terrorism exception, however, by its application to only those nations designated as state sponsors of terrorism, ${ }^{182}$ re-injects the unpredictable political element that the drafters of the FSIA desperately tried to remove. By designating or rescinding a determination of sponsorship of terrorism, the State Department "is able to control which states are granted immunity and which are not." ${ }^{\text {,183 }}$ Consequently, this exception "appears to be grounded not in principle, but in political accommodation." ${ }^{\text {184 }}$ By limiting the statesponsored terrorism exception to only designated states, the exception "differentiates the rights of victims based on who committed the wrong, rather than determining a victim's rights with reference to the

${ }^{180}$ See supra Part I.C (summarizing Monroe Leigh's argument in favor of enacting the FSIA, which would align the U.S. system with international norms and promote clear guidance for U.S. plaintiffs).

${ }_{181}$ See Miguel Angel Gonzalez Felix, The Foreign Sovereign Immunities Act: Fair Play for Foreign States and the Need for Some Procedural Improvements, 8 HOUS. J. INT'L L. 1, 10 (1985) ("Congress sought to depoliticize the issue of sovereign immunity by placing the responsibility for its resolution exclusively in the hands of the judiciary."); RohtArriaza, supra note 86, at 72-73 ("[O]ne of the FSIA's principal objectives was to transfer the determination of sovereign immunity from the State Department to the courts ..., remov[ing] the unpredictability and uncertainty inherent in the existing system, and remov[ing] the diplomatic pressures on the executive branch to influence the process."); MacKusick, supra note 42, at 769 ("One of the main purposes of enacting the FSIA was to transfer the decision making process regarding immunity determinations from the executive branch to the judicial branch ... to remove the process from political pressures and to allow the judiciary to make the determination based upon well defined criteria.").

${ }^{182}$ See 28 U.S.C. $\S 1605$ (a) (7)(A) (1994 \& Supp. II 1996) (acknowledging that jurisdiction under the FSIA will be denied unless the nation that sponsored the attack has been designated as a sponsor of terrorism pursuant to section 6(j) of the Export Administration Act of 1979 or section 620A of the Foreign Assistance Act of 1961). The Secretary of State makes such determinations and publishes the list in the Federal Register. As of this writing, Iran, Libya, North Korea, Sudan, and Syria have all been designated as state sponsors of terrorism. See 59 Fed. Reg. 51,130, 51,131 (1994) (to be codified at 48 C.F.R. pt. 209) (listing those nations that the Secretary of State has identified as "terrorist countries" pursuant to section 6(j) of the Export Administration Act of 1979).

${ }^{189}$ MacKusick, supra note 42, at 770.

${ }^{184}$ Bucci, supra note 43 , at 317. 
nature of the wrong." 185 Inevitably, focusing on the actor rather than on the action when determining which nations are subject to liability will result in a decision to punish only those states that have been stigmatized as "terrorist nations" by the State Department. ${ }^{186}$ Furthermore, AEDPA also permits the Attorney General to stay any discovery upon certifying that such investigation "would significantly interfere with a criminal investigation or prosecution, or a national security operation, related to the incident that gave rise to the case of action. ${ }^{, 187}$ In making such determinations, political factors will inevitably enter the calculus. While there is no argument that Congress has the power to place such determinations within the purview of the Secretary of State ${ }^{\mathrm{I} 88}$ and to empower the Attorney General to stay discovery, it is important to note that by implementing these regulations, Congress drastically deviates from the steady apolitical course the FSIA has forged.

\section{Attachment and Substantive Causes of Action}

Part II, thus far, has focused on how AEDPA's state-sponsored terrorism exception represents a profound deviation from the established doctrine of sovereign immunity. This Act, however, includes other sections, which also deviate from this steady course. Specifically, the new attachment provisions ${ }^{189}$ represent a significant departure

${ }^{185} \mathrm{Id}$. at $317-18$.

${ }^{186}$ See Stephen J. Schnably, International Decisions, Alejandre v. Republic of Cuba, 92 AM. J. INT'L L. 768, 771 (1998) (summary of case) (opining that one should not "expect strategic foreign policy considerations to play no role in the handling of human rights matters by the political branches. It would be unfortunate, however, if the judiciary's role in redressing human rights violations abroad were subordinated to the aim of punishing states on an enemies list").

${ }^{187} 28$ U.S.C. $\S 1605$ (g)(1)(A) (Supp. III 1997). See generally Joseph M. Terry, Comment, Jurisdictional Discovery Under the Foreign Sovereign Immunities Act, 66 U. CHI. L. REV. 1029, 1043-59 (1999) (detailing the problems with the discovery provisions of the 1996 amendments and arguing for an alternative approach).

${ }^{183}$ See Rein v. Socialist People's Libyan Arab Jamahiriya, 995 F. Supp. 325, 330 (E.D.N.Y. 1998) ("The Secretary's designation [is] ... accorded to a foreign state by Congress and the Executive in their exclusive and discretionary exercise of their foreign affairs powers under the Constitution.").

${ }^{189} 28$ U.S.C. $\$ 1610$ (a) (7) (Supp. III 1997) provides:

(a) The property in the United States of a foreign state... used for a commercial activity in the United States, shall not be immune from attachment in aid of execution ... if-

(7) the judgment relates to a claim for which the foreign state is not immune under section 1605 (a) (7), regardless of whether the property is or was 


\section{from traditional practice.}

While the practical implications of the amended attachment provision will be explored below, ${ }^{190}$ it is important to note that permitting the attachment of a foreign state's property, without any nexus to the incidents which serve as the basis of the withdrawal of immunity, is a substantial break with precedent. ${ }^{191}$ All other prejudgment attachments have required a connection to the activity or an explicit waiver of immunity from such attachment. ${ }^{192}$ Congress enacted these requirements as a result of the fear that American property abroad could be exposed to reciprocal treatment. ${ }^{193}$ While the State Department admonished expanding the scope of prejudgment attachment to include attaching all state property regardless of connection, ${ }^{194}$ AEDPA's attachment provision creates such a result.

Finally, the Flatow Amendment itself represents an unreasonable deviation from the evolution of sovereign immunity. Although the FSIA, as amended by AEDPA, withdraws the cloak of immunity, the Flatow Amendment creates a substantive cause of action enabling recovery for personal injury or death committed by any "official, employee, or agent of a foreign state designated as a state sponsor of terrorism... while acting within the scope of his or her office, employment, or agency." "195 This additional cause of action is significant "because the FSIA as otherwise enacted is not intended to affect the substantive law of liability in actions against foreign states." ${ }^{196}$ By

\footnotetext{
involved with the act upon which the claim is based. Id.

${ }^{190}$ See infra Part III (discussing the practical consequences of civil suits under the amendments).

${ }^{191}$ See Murphy, supra note 75, at 456 ("Normally, the property of a foreign state is immune from attachment or execution if the property was not involved with the act upon which the claim is based."); see also Borek Statement, supra note 49, at 14 ("Execution against the property of a foreign state ... is narrowly circumscribed by section 1610 , which permits execution against the property of a foreign state only if the property is used for a commercial activity in the United States, and then only in specifically defined circumstances.").

${ }^{192}$ See Borek Statement, supra note 49, at 13 (noting that the amendment would eliminate any nexus requirement and would allow prejudgment attachment without waiver by the foreign state).

193 See id. at 15 (noting that the exposure of U.S. government property abroad dictates curtailing prejudgment attachment).

${ }^{194}$ See id. (opposing "proposals that would permit pre-judgment attachment without a waiver").

${ }^{195} 28$ U.S.C. $§ 1605$ (1994 \& Supp. III 1997) (quoting Pub. L. No. 104-208).

${ }^{196}$ John F. Murphy, Civil Liability for the Commission of International Crimes As an Alternative to Criminal Prosecution, 12 HARV. HUM. RTS. J. 1, 39 (1999); see also Flatow v. Islamic Republic of Iran, 999 F. Supp. 1, 13 (D.D.C. 1998) ("[T] he state sponsored ter-
} 
providing an additional remedy, the amendment clearly violates the purpose of the FSIA. ${ }^{197}$

\section{JUDGMENTS RENDERED, CLOSURE DENIED: THE PRACTICAL CONSEQUENCES OF CIVIL SUITS UNDER THE 1996 AMENDMENTS}

The consequences of the recent amendments are not limited to mere theoretical concerns. The recent suits filed pursuant to these amendments have demonstrated, in practice, that private suits have neither resulted in a decrease in state-sponsored terrorism nor provided the accountability and closure that victims' families seek through recourse to the private suit. ${ }^{198}$ The only result of such private suits has been an increase in the number of suits brought. ${ }^{199}$ Coupling these practical consequences with the theoretical concerns, however, ultimately leads one to conclude that the experiment of the private suit has failed and recourse to such suits must be reexamined.

Before analyzing the practical consequences of such suits, a brief background of these cases is necessary. The first suit filed pursuant to the recent amendments to the FSIA was Alejandre v. Republic of Cuba. ${ }^{200}$ The facts which gave rise to the civil suit in Alejandre are the same facts which persuaded Congress to enact the Helms-Burton Act. ${ }^{201}$ On Feb-

rorism exception ... is a remedial statute. It creates no new responsibilities or obligations; it only creates a forum for the enforcement of pre-existing universally recognized rights under federal common law and international law.").

${ }^{197}$ See Liu v. Republic of China, 892 F.2d 1419, 1425 (9th Gir. 1989) ("The FSIA does not create a federal rule of liability to be applied in an action involving a foreign state."); H.R. REP. No. 94-1487, at 12 (1976), reprinted in 1976 U.S.C.C.A.N. 6604, 6610 (stating " $[t]$ his bill is not intended to affect the substantive law of liability").

${ }^{193}$ See Gerson, supra note 12 ("It gives the victims of terrorism and their families what they desire more-accountability, the opportunity to get the true facts out in the open and thus to obtain closure to their own personal trials while at the same time preventing state-sponsors of terrorism from evading responsibility.").

${ }^{199}$ See, e.g., Dirk Johnson, Joumalist Held Hostage in Lebanon Sues Iran, N.Y. TIMES, Mar. 23, 1999, at A14 (stating that ex-hostage Thomas Sutherland plans on filing a suit against Iran for its role in his imprisonment in Lebanon); Bill Miller, Ex-Hostage Anderson Files Suit Against Iran, WASH. POST, Mar. 23, 1999, at A5 (reporting that Terry Anderson filed a $\$ 100$ million lawsuit against Iran for sponsoring the terrorist organization that held him captive for seven years); Parents of Bomb Victims Sue Iran in U.S. Court, RECORD, N. N.J., Feb. 10, 1999, at All, available in 1999 WL 7089054 (describing a suit brought against Hamas, an Islamic militant group, which claimed responsibility for a terrorist attack killing two American students, Sara Duker and MatthewEisenfeld).

200996 F. Supp. 1239 (S.D. Fla. 1997). There is a subtle irony in the fact that the first suit filed under the Flatow Amendment was not the Flatow case itself.

${ }^{201}$ See Cuban Liberty and Democratic Solidarity (LIBERTAD) Act of 1996, Pub. L. No. 104-114, 110 Stat. 785, 804-05 (codified at 22 U.S.C.A. $\$ \S 6021-6091$ ) (stating, in 
ruary 24, 1996, the Cuban Air Force, upon orders of the government of Cuba, and "in outrageous contempt for international law and basic human rights," shot down two unarmed civilian planes over international waters as they searched for rafters in the waters between Cuba and Florida. ${ }^{202}$ As a result of this unprovoked attack, four individuals were killed.

Three of the victims' families ${ }^{203}$ brought suit against the Republic of Cuba and the Cuban Air Force pursuant to the recent amendments to the FSIA. Neither the Cuban government, nor the Cuban Air Force, entered an appearance. ${ }^{204}$ Since federal law prohibits the entering of a default judgment against a foreign government, the court acknowledged Cuba's default, and held a hearing to determine whether the plaintiff's allegations were supported by the evidence. ${ }^{205}$

In order to remove the presumption of foreign sovereign immunity, the plaintiffs invoked $\S 1605(\mathrm{a})(7)$ of the FSIA ${ }^{206}$ Having done

$\$ 6046$, congressional findings of fact relating to the shooting down of Brothers to the Rescue aircraft); Alejandre, 996 F. Supp. at 1247 (noting that the Cuban government's actions precipitated the enactment of the LIBERTAD Act); Schnably, supra note 186, at 768 (the incident "prompted Congress to enact the controversial Helms-Burton Act"). This incident also provoked the animosity of the international community. See Alejandre, 996 F. Supp. at 1246-47 (acknowledging the international condemnation of the unprovoked attack).

${ }_{202}$ The civilian planes were part of a Miami-based humanitarian organization called "Brothers to the Rescue" [Hermanos al Rescate]. The purpose of this organization is "to search the Florida Straits for rafters, Cuban refugees who had fled the island nation on precarious inner tubes or makeshift rafts .... Brothers to the Rescue would locate the rafters and provide them with life-saving assistance by informing the U.S. Coast Guard of their location and condition." Id. at 1243.

${ }^{203}$ Since one of the requirements of the state-sponsored terrorism exception is that the victims must be nationals of the United States, one of the victims, not an American citizen, could not join as a party to the suit. See id. at 1242; see also 28 U.S.C. $\$ 1605$ (a) (7) (B) (ii) (Supp. III 1997) (denying the waiver of immunity when the victims or claimants under this exception are not nationals of the United States).

${ }^{204}$ Although Cuba did not enter an appearance, the court did note that Cuba objected, in a diplomatic note, to the court's exercise of jurisdiction over it and its political subdivision. See Alejandre, 996 F. Supp. at 1242 (describing Cuba's objection to suit).

${ }^{205}$ See 28 U.S.C. $\$ 1608$ (e) (1994) (providing that upon default by a foreign government, claimants must establish their "claim or right to relief by evidence satisfactory to the court"); see also Alejandre, 996 F. Supp. at 1242 n.1 ("Congressional purpose behind this section was to protect foreign states from 'unfounded default judgments rendered solely upon a procedural default." (quoting Compania Interamericana Export-Import S.A. v. Compania Dominicana de Aviacion, 88 F.3d 948, 950-51 (11th Cir. 1996))).

${ }^{205}$ The court concluded that the plaintiffs fulfilled all the requirements of $\$ 1605(a)(7)$ : first, the United States has designated Cuba as a state-sponsor of terrorism; second, the Cuban Air Force was acting as an agent of the Cuban government; third, the act occurred outside the foreign state; and fourth, the claimants and victims 
so, the plaintiffs then predicated liability against the Cuban Air Force and the Republic of Cuba, through respondeat superior liability, pursuant to the Flatow Amendment. ${ }^{207}$ The court excerpted at length the radio communications between the Cuban Air Force and the military controls in Havana to demonstrate that the attack on the civilian plane was pursuant to Cuba's orders. ${ }^{208}$ Persuaded by this evidence, the court concluded that "both the Cuban Air Force and Cuba are liable for the murders of Alejandre, Costa, and De la Pena" and consequently entered judgment for the plaintiffs. ${ }^{209}$

Having concluded that the Cuban government and air force were liable, the trial progressed to the damages phase. Guided by the Flatow Amendment, ${ }^{210}$ the court noted the Cuban Air Force would be liable for both compensatory and punitive damages. ${ }^{211}$ Since the FSIA explicitly prohibits the imposition of punitive damages against a foreign state itself, ${ }^{212}$ the court held that Cuba, by virtue of respondeat superior liability, would be liable only for compensatory damages. ${ }^{213}$ The final damage judgment awarded $\$ 187,627,911 \quad(\$ 49,927,911$ in compensatory damages assessed against both Cuba and its air force and $\$ 137,700,000$ in punitive damages assessed against the Cuban Air Force alone). ${ }^{214}$

The second decision rendered pursuant to the recent amendments, Flatow v. Islamic Republic of Iran, ${ }^{215}$ contains, perhaps, the most

were U.S. nationals at the time the acts occurred. See Alejandre, 996 F. Supp. at 1247-48 (listing the requirements of $\$ 1605(\mathrm{a})(7)$ and examining the facts of the case in light of each requirement).

${ }^{207}$ See id. at 1249 (observing that the statute essentially makes states liable for its agents or employees).

${ }^{203}$ See id. at 1244-46 (excerpting radio communications from Cuban military control giving authorization to destroy the aircraft).

${ }_{209}$ Id. at 1249.

${ }^{210}$ See 28 U.S.C. \$ 1605 note (Supp. III 1997) (providing "money damages which may include economic damages, solatium, pain, and suffering, and punitive damages" for actions brought pursuant to any action covered by the state-sponsored terrorism exception, $\$ 1605(\mathrm{a})(7))$.

${ }^{211}$ See Alejandre, 996 F. Supp. at 1249 ("Under the theory of respondeat superior, Cuba is liable for the same amount of damages as its agent, with the exception of punitive damages, which the FSIA prohibits against foreign states.").

${ }^{212}$ See 28 U.S.C. $\$ 1606$ (1994) ("[T]he foreign state shall be liable in the same manner and to the same extent as a private individual under like circumstances; but a foreign state except for an agency or instrumentality thereof shall not be liable for punitive damages.").

${ }^{213}$ See Alejandre, 996 F. Supp. at 1253 (holding Cuba liable for compensatory damages and the Cuban Air Force liable for compensatory and punitive damages).

${ }^{214}$ See id. (detailing breakdown of total award amount).

${ }^{215} 999$ F. Supp. 1 (D.D.C. 1998). 
thorough treatment of the complex issues of liability and damages. ${ }^{216}$ Alisa Flatow, a junior at Brandeis University, was studying in Israel when she was killed by a suicide-bomber attack on a tour bus en route to Gush Katif as the bus traveled through the Gaza Strip. ${ }^{217}$ The next day, the Shaqaqi faction of the Palestine Islamic Jihad claimed responsibility for the attack. ${ }^{218}$ By contacting the State Department and conducting their own investigation, the Flatows were able to trace money from the Iranian government directly to this terrorist organization. ${ }^{219}$ Fueled by their desire to hold Iran accountable for this attack and armed with the Flatow Amendment, Alisa's family filed suit against Iran.

As with the Cuban government in Alejandre, the Iranian government did not enter an appearance. ${ }^{220}$ The position of the Iranian government, despite its failure to enter an appearance or to issue any diplomatic notice, was clear: the United States lacked jurisdiction to hear this case. ${ }^{221}$ The court, as it did in Alejandre, examined the plaintiffs' evidence and entered several conclusions of fact and law. The court ultimately found that Iran was responsible for the killing of Alisa Flatow by a member of the Shaqaqi faction of the Palestine Islamic Jihad "under the direction of Iran." ${ }^{\text {"222 }}$ In awarding damages, the court did not feel as constrained as the Alejandre court did and assessed both compensatory and punitive damages against Iran. ${ }^{223}$ Under the doc-

${ }^{216}$ For a detailed case analysis of Flatow, see Ethan J. Early, Note, Flatow v. Islamic Republic of Iran and the Foreign Sovereign Immunities Act: Is Peace of Mind Enough?, 14 CONN. J. INT'L L. 203 (1999) (examining Flatow in relation to the FSIA).

217 See Flatow, 999 F. Supp. at 6-10 (detailing the court's finding of facts).

${ }^{218}$ As the court noted, the "Shaqaqi faction is a terrorist cell [of the Palestine Islamic Jihad] with a small core membership. Its sole purpose is to conduct terrorist activities in the Gaza region, and its sole source of funding is the Islamic Republic of Iran." Id. at 8.

${ }^{219}$ See 60 Minutes, supra note 1 (noting that copies of the Iranian Budget for 1995 blatantly detailed an expenditure of " $\$ 20$ million to support [the] Palestine Islamic revolution").

${ }^{220}$ See Flatow, 999 F. Supp. at 6 (noting that "[d] efendants have not entered an appearance in this matter").

${ }^{221}$ In fact, the Iranian government, "an experienced litigant in the United States federal court system," effectively tried to evade service of process by writing "DO NOT USA" on the back of the service package and returned the package to the United States. Id. at 6 n.1; see also Bill Miller \& John Mintz, Once-Supportive U.S. Fights Family over Iranian Assets, WASH. POST, Sept. 27, 1998, at A8 (quoting Mahmoud Mohammadi, an employee of Iran's Foreign Ministry, as questioning, "How can one judge of a country issue a verdict against a sovereign foreign government?").

${ }^{222}$ Flatou, 999 F. Supp. at 10.

${ }^{223}$ See infra notes 258-64 and accompanying notes (discussing this award of punitive damages). 
trine of respondeat superior and vicarious liability, the court awarded the plaintiffs $\$ 225$ million in punitive damages. ${ }^{224}$ Adding this punitive damage award to the compensatory damages, the damages awarded for the pain and suffering endured by Alisa, and solatium damages brought the total damage award to $\$ 247.5$ million. ${ }^{225}$

On of the most recent judgments rendered pursuant to the statesponsored terrorism exception is Cicippio v. Islamic Republic of Iran. ${ }^{226}$ Joseph Cicippio, ${ }^{227}$ Frank Reed, ${ }^{228}$ and David Jacobsen ${ }^{229}$ were three of the eighteen American hostages held captive in Lebanon by Hizballah, "a politico-paramilitary organization sponsored, financed, and controlled by Iran." 230 These three men, on behalf of themselves and on behalf of two of their spouses, ${ }^{231}$ filed suit pursuant to the recent amendments to the FSIA.

As in the Flatow case, Iran failed to enter an appearance, and a hearing proceeded ex parte. ${ }^{232}$ Based on the evidence provided by the

224

In this Court's judgment, in order to ensure that the Islamic Republic of Iran will refrain from sponsoring such terrorist acts in the future, an award of punitive damages in the amount of three times the Islamic Republic of Iran's annual expenditure for terrorist activities [of $\$ 75$ million] is appropriate.

Flatow, 999 F. Supp. at 34.

${ }^{225}$ See id. at 5 (detailing the damages of the award).

${ }^{226} 18$ F. Supp. 2d 62 (D.D.C. 1998).

${ }^{297}$ Joseph Cicippio, Comptroller of the American University of Beirut, was kidnapped on September 12, 1986 and imprisoned for 1908 days. See id. at 64, 66. While imprisoned, Cicippio was subjected to "terrifying interrogation," threats of castration, Russian roulette, and random beatings. Id. at 66 . He was confined in "rodent-and scorpion-infested cells, and for virtually his entire time in captivity he was bound by chains." Id. As a result of his imprisonment, Cicippio lost 60 pounds and developed serious physical problems which still affect him today. See id.

${ }_{223}$ Frank Reed, co-owner and operator of two private schools in Beirut, was abducted on September 9,1986 and "kept in solitary confinement for two years blindfolded and chained to the wall or floor." Id. at 64-65. Apart from daily torture and death threats, electric shocks were administered to Reed's hands and, after one of his attempts to escape, he was forced to kneel on spikes. See id. at 65.

${ }^{229}$ David Jacobsen, Chief Executive Officer of the American University of Beirut Medical Center, was abducted on May 28, 1985 and held captive for 18 months. See id. at 64 . Clothed in only underwear and a T-shirt, Jacobsen was subjected to regular beatings and mental torture. See id. at 65.

${ }_{230}$ Id. at 64 ("Hizballah's mission was to exploit the disorder in Lebanon following the Israeli military incursion of 1982 and to diminish American influence in the region."); see also Miller \& Mintz, supra note 221 (describing the kidnapping and torturing of these three hostages).

${ }_{231}$ Elham Cicippio and Fifi Dalati-Reed were both named plaintiffs and testified at trial to the mental anguish they suffered while their husbands were imprisoned. See Cicippio, 18 F. Supp. 2d at 66-67 (summarizing their testimony).

${ }_{282}$ See id. at 64 (noting that service was effected on April 28, 1997, but that Iran did 
plaintiffs, the court concluded that all the requirements of the statesponsored terrorism exception were met: (1) the plaintiffs were injured by acts of torture; (2) the acts were committed by a statesupported terrorist group; (3) material support was provided by Iranian officials engaged within the scope of their employment; (4) Iran was, at the time, designated as a state sponsor of terrorism; (5) the claimants and victims were nationals of the United States; and (6) similar acts by U.S. officials, if performed within the scope of their employment, would give rise to a cause of action. ${ }^{233}$ The court awarded compensatory damages in the following amounts: Joseph Cicippio ( $\$ 20$ million); Elham Cicippio ( $\$ 10$ million); Frank Reed ( $\$ 16$ million); Fifi Delati-Reed ( $\$ 10$ million); and David Jacobsen ( $\$ 9$ million). ${ }^{234}$

Having briefly summarized the decided cases, it is possible to deduce some common practical consequences of these decisions. These consequences clearly demonstrate the inability of private civil suits, on a practical level, to effectuate the stated purpose of the amendments and to provide the accountability and closure that impelled the litigants to file suit in the first place.

\section{A. Pre-Trial Consequences}

By limiting the class of potential defendants only to those designated as state sponsors of terrorism, the new amendments to the FSIA have drastic practical consequences even at the pre-trial level. Unless a state that commits the terrorist act has been designated by the State Department as a state sponsor of terrorism, the victims of such attacks have no recourse under the terrorism exception to the FSIA. ${ }^{235}$ Yet, unlike litigants in most of the other enumerated exceptions to the FSIA who purposefully chose to engage in the activity with the foreign nation that gave rise to the suit, victims of state-sponsored terrorism have not made such a choice. Limiting the recourse of these litigants

not enter an appearance).

${ }^{233}$ See id. at 68 (summarizing the plaintiffs' evidence).

${ }^{23}$ Unlike the court in Flalow, however, the court followed the Alejandre court's example and refrained from issuing punitive damages. See id. at 69 ("[T] he Court must undertake the difficult task of calculating an award of compensatory damages to make plaintiffs whole, while nevertheless avoiding any punitive component that would surely accompany a compensatory award were the defendant at bar not possessed of statutory immunity.").

${ }^{235}$ See 28 U.S.C. $\$ 1605$ (a) (7)(A) (Supp. III 1997) (providing that foreign states shall not be immune to U.S. jurisdiction if they are "designated as a state sponsor of terrorism"). 
to a political determination of the State Department over which these individuals have no control is profoundly unfair.

While this limitation was not an obstacle to the plaintiffs in Alejandre, Flatow, and Cicippio, the case of Scott Nelson provides a clear example of the inequity of this situation. ${ }^{236}$ Scott Nelson, an American citizen, worked as a monitoring systems engineer at King Faisal Specialist Hospital in Riyadh, Saudi Arabia. ${ }^{237}$ Although his employment progressed largely without incident, in March of 1984, Nelson first advised hospital officials about "safety defects in the hospital's oxygen and nitrous oxide lines." ${ }^{238}$ A few months later, Nelson was summoned "to the hospital security office where agents of the Saudi government arrested him." ${ }^{239}$ Upon his arrest, Nelson was shackled, tortured, beaten, and kept for four days without food. ${ }^{240}$

Nelson, finally released after a thirty-nine day detention, filed suit against Saudi Arabia. Since he commenced this suit prior to the enactment of $\S 1605$ (a) (7), Nelson was forced to pursue recourse within $\S 1605$ (a) (2)-the commercial activity exception. The district court dismissed the action for lack of jurisdiction since Nelson failed to allege a sufficient nexus between his recruitment in the United States and the injuries sustained to permit a finding of "commercial activity. ${ }^{241}$ Although the Court of Appeals reversed, ${ }^{242}$ the Supreme Court agreed with the district court and barred Nelson's suit. ${ }^{243}$

While the state-sponsored terrorism exception was designed to remedy this exact situation, ${ }^{244}$ Nelson still has no recourse. Since Saudi Arabia has not been designated as a sponsor of terrorism, it is not amenable to suit and retains its sovereign immunity. ${ }^{245}$ Placing

${ }^{206}$ See Bucci, supra note 43, at 316-19 (detailing the circumstances surrounding the Nelson case).

${ }^{237}$ See Saudi Arabia v. Nelson, 507 U.S. 349, 352 (1993) (describing the circumstances of Nelson's employment in Saudi Arabia).

2si Id.

259 $I d$.

${ }^{240}$ See id. at 353.

241 Id. at 354. Nelson argued that Saudi Arabia had acted in a "commercial manner" by recruiting employees in the United States, and that the commercial activity exception therefore applied. Id.

${ }^{242}$ See 923 F.2d 1528 (11th Cir. 1991), rev'd, 507 U.S. 349 (1993).

${ }^{243}$ See Nelson, 507 U.S. at 363 (reversing the Court of Appeals).

${ }^{244}$ See supra Part II.A.2 (discussing development of the passive personality principle to escape the nexus requirement).

${ }^{215}$ See Defense Federal Acquisition Regulation Supplement: Terrorist Countries, supra note 83 (identifying terrorist countries as Cuba, Iran, Iraq, Libya, North Korea, Sudan, and Syria). 
emphasis on the actor, rather than on the action itself, subjects the victims of terrorism to the uncertain political climate of foreign relations-a situation over which they have no control. As Daniel Wolf, counsel for Scott Nelson, stated, "[t] here is no... principled reason for providing redress in our courts for American citizens who are tortured by officials of foreign states on the Department's list, but denying such redress to Americans who are tortured by officials of other countries." ${ }^{246}$ Denying relief for terrorist acts committed by nations not designated as state sponsors of terrorists leads one inevitably to question the true focus of U.S. counter-terrorism policy.

\section{B. Trial Consequences}

Beyond such pre-trial considerations, civil suits pursuant to the recent amendments also demonstrate serious practical consequences at the trial phase which courts cannot ignore. First of all, despite initial commentary predicting that foreign nations would appear in actions brought against them, ${ }^{247}$ all three decided cases have proceeded ex parte. ${ }^{248}$ Proceeding with a trial without the participation of the for-

${ }^{215}$ Victims of Torture: Hearings Before Subcomm. on Int'l Operations and Human Rights of the House Comm. on Int'l Relations, 104th Cong. 88 (1996) (statement of Daniel Wolf).

${ }^{247}$ See Sofaer Statement, supra note 107, at 84 ("The concern that this legislation will result in unenforceable default judgments is equally unpersuasive.... In most instances ... a foreign state will appear and assert its rights, rather than exposing its property to attachment.").

${ }_{243}$ See Cicippio v. Islamic Republic of Iran, 18 F. Supp. 2d 62, 64 (D.D.C. 1998) (noting that Iran was served with process but did not respond to the complaint or enter an appearance); Flatow v. Republic of Iran, 999 F. Supp. 1, 6 n.1 (D.D.C. 1998) (noting that Iran gave no response to service of process and made no appearance); Alejandre v. Republic of Cuba, 996 F. Supp. 1239, 1242 (S.D. Fla. 1997) (noting that Cuba objected to jurisdiction in a diplomatic note but failed to respond or enter an appearance).

It is important to note that another case filed pursuant to the terrorism exception to the FSIA has not resulted in a default judgment thus far. Although this case has yet to come to trial, Rein v. Socialist People's Libyan Arab Jamahiriya might be the first case under the recent amendments not to result in a default judgment. This case is the next chapter in the Smith saga. See supra notes 65-74 and accompanying text (examining the inability of the plaintiffs in Smith v. Socialist People's Libyan Arab Jamahiriya, 886 F. Supp. 306 (E.D.N.Y. 1995), to assert any claims against Libya under the FSIA, as originally enacted). After Smilh was dismissed for lack of jurisdiction, the plaintiffs in that case filed suit against Libya under the new terrorism exception. Libya, unlike Iran and Cuba, contested the exercise of jurisdiction and filed a motion to dismiss. This motion was denied by both the district court, 995 F. Supp. 325 (E.D.N.Y. 1998), and the Court of Appeals for the Second Circuit, 162 F.3d 748 (2d Cir. 1998). On June 14, 1999, the Supreme Court declined to issue a writ of certiorari. See Socialist People's Libyan Arab Jamahiriya v. Rein, 119 S. Ct. 2337 (1999). It remains to be seen whether or not Libya will actually proceed to trial. 
eign nation has serious consequences on a number of levels.

From an international perspective, allowing cases to proceed ex parte erodes the credibility of the FSIA. Although "defaults are not favored by the FSIA, they are available pursuant to section $1608(\mathrm{e}) .^{{ }^{249}}$ After the court enters a default, it must still determine whether the plaintiff's allegations are supported by evidence. ${ }^{250}$ Yet, in making that determination, the court need not hold a hearing or make any explicit findings, as long as the record shows that the plaintiff provided enough evidence to support his claim. ${ }^{251}$ In fact, the burden of proof overall is "less than if defendants had participated in discovery." Proceeding to enter findings of fact and law without the participation of the foreign state clearly "create[s] the impression that the primary motive behind such action is not a concern for human rights but the pursuit of partisan political ends. "253

Furthermore, in amending the FSIA, the State Department admonished that "[n]ot only do we [the United States] look to the FSIA as a guide in asserting our own immunity abroad, but foreign states themselves may well apply [the FSIA's] standards against us, as a matter of reciprocity. ${ }^{254}$ Thus, there is the inherent risk that foreign nations will enact legislation denying sovereign immunity for acts for which the United States considers itself immune. ${ }^{255}$ Consequently, when such actions are brought against the United States in foreign courts, and the United States, based upon jurisdictional objections,

219 EPSTEN ET AL., supra note $155, \S 7.16$.

${ }^{250}$ See 28 U.S.C. $\$ 1608$ (e) (1994) ("No judgment by default shall be entered ... unless the claimant establishes his claim or right to relief by evidence satisfactory to the court.").

${ }_{231}$ See EPSTEIN ET AL., supra note 155, $\$ 7.16$ (quoting Commercial Bank of Kuwait v. Rafidain Bank, 15 F.3d 238, 242 (2d Cir. 1994)).

${ }^{252}$ Id. (quoting Dibrell Bros. Tobacco, Inc. v. Rafidain Bank, No. 93-0993, 1994 U.S. Dist. LEXIS 8271 (D.D.C. June 14, 1994)).

${ }^{253}$ SCHREUER, supra note 60 , at 60 .

${ }^{234}$ Borek Statement, supra note 49, at 12.

255 See JOHN F. MURPHI, STATE SUPPORT OF INTERNATIONAL TERRORISM: LEGAL, POLITICAI, AND ECONOMIC DIMENSIONS 119 (1989) ("Such proceedings, moreover, could result in retaliatory actions against the United States in the courts of other countries that might be inclined to define terrorism and state sponsorship of it quite differently from any definition appearing in U.S. legislation or adopted by U.S. courts."); see also The Foreign Sovereign Immunities Act: Hearing on S. 825 Before the Subcomm. on Courts and Admin. Practice of the Senale Comm. on the Judiciary, 103d Cong. 8 (1994) (statement of Stuart Schiffer, Deputy Assistant Attorney General, U.S. Department of Justice) [hereinafter Schiffer Statement] ("If other states were to expand the jurisdiction of their own courts, they might sweep more broadly into areas which we consider to be properly immune from their jurisdiction."). 
refuses to respond, ${ }^{256}$ such foreign courts may proceed ex parte as a matter of reciprocity. Once such a judgment is rendered, American property abroad could be subject to attachment in order to satisfy these judgments.

From a mere personal perspective, proceeding ex parte does not provide litigants with what they desire most-accountability and closure. ${ }^{257}$ This is not to suggest that if a foreign state were to appear in the trial, it would throw itself upon the mercy of the court and disclose all the atrocities it committed. Yet, subjecting the foreign state to the trial process in the United States and requiring it to appear before the court to answer for what has occurred provide significant emotional and psychological benefits to the plaintiffs that simply do not exist in the default judgment process. Witnessing foreign officials answering questions and undergoing cross examination helps these families heal and puts a face on their children's torturers. By noting a nation's default but proceeding without its participation, the court is allowing the terrorist nation to add insult to injury.

Experiences at the trial level have also shown that some courts seize upon the new amendments as a vehicle to expand the FSIA to even greater impermissible lengths. Although the intent of the recent amendments was remedial in nature, ${ }^{258}$ courts have used the amendments to further new and unspecified goals. A clear example of this impermissible expansion is demonstrated by the Flatow court's award of punitive damages against Iran.

The FSIA clearly states that a foreign sovereign that is "not entitled to immunity under section 1605 or $1607 \ldots$ shall be liable in the same manner and to the same extent as a private individual under like circumstances; but a foreign state except for an agency or instrumentality thereof shall not be liable for punitive damages. ${ }^{\text {.259 }}$ Despite the clarity of this language, the Flatow court reached a different conclusion. Judge Lamberth noted that "a foreign state sponsor of terrorism can still be indirectly liable for punitive damages under the principles

${ }^{256}$ See Borek Statement, supra note 49 , at 14 (noting that " $[s]$ tates are generally reluctant to enter into the domestic courts of another state to defend themselves against charges of serious violations of law").

${ }_{257}$ See Gerson, supra note 12 ("[Civil suits] give[] the victims of terrorism and their families what they desire most-accountability, the opportunity to get the true facts out in the open and thus to obtain closure to their own personal trials ....").

${ }^{25 s}$ See supra Part II.D (noting that the recent amendments were enacted to rectify the problem of invoking the noncommercial tort exception for acts of state-sponsored terrorism).

${ }^{259} 28$ U.S.C. § 1606 (1994). 
of respondeat superior and vicarious liability." ${ }^{260}$ The court reasoned that compensatory damages cannot possibly provide the "massive civil liability" ${ }^{261}$ that the state-sponsored terrorism exception was designed to provide. As a result, the court concluded that a punitive damage award "in the amount of three times the Islamic Republic of Iran's annual expenditure for terrorist activities is appropriate. ${ }^{262}$

An award of punitive damages, however, undermines both the letter and the intent of the FSIA. Not only does it flatly contradict the clear statutory language of $\S 1606$, but it also contradicts the intent of the FSIA which was "not intended to affect the substantive law of liability."263 Although no other court has followed the Flatow court's lead, ${ }^{264}$ such an unwarranted expansion of the FSIA ultimately foreshadows what lies ahead.

\section{Post-Trial Consequences}

The most devastating consequences of civil suits pursuant to the recent amendments occur during the post-trial phase: execution of the judgments. Simply obtaining a judgment against the foreign state does not effectuate the amendments' desired goal of deterring future acts of terrorism by imposing massive civil liability upon the foreign nation. ${ }^{265}$ To achieve this goal, the judgments must be enforced. Although supporters of the recent amendments claimed that "the imposition of a default judgment will create pressure ... to settle the dispute, ${ }^{, 66}$ the recent cases decided pursuant to the terrorism exception have demonstrated the complete inability of litigants to execute their

${ }^{260}$ Flatow v. Islamic Republic of Iran, 999 F. Supp. 1, 25-26 (D.D.C. 1998); see also Murphy, supra note 75, at 41 (describing the award of punitive damages as "[t] he most notable and surprising aspect of the court's decision in Flatow").

${ }^{261}$ Flatow, 999 F. Supp. at 25; see also 144 CONG. REC. H1095 (daily ed. Mar. 11, 1998) (statement of Rep. Saxton) [hereinafter Saxton Statement] (stressing that the goal of civil suits is to hit foreign nations where they hurt the most-in the pocketbook).

${ }^{262}$ Flatow, 999 F. Supp. at 34. Iran's annual expenditure for terrorist activities is $\$ 75$ million. See id.

${ }^{269}$ H.R. REP. NO. 94-1487, at 12 (1976), reprinted in 1976 U.S.C.C.A.N. 6604, 6610.

${ }^{294}$ See Cicippio v. Islamic Republic of Iran, 18 F. Supp. 2d 62, 69 (D.D.C. 1998) (noting the difficulty of awarding compensatory damages in the absence of punitive damages but nonetheless denying an award of punitive damages); Alejandre v. Republic of Cuba, 996 F. Supp. 1239, 1249 (S.D. Fla. 1997) (assessing compensatory damages against Cuba, but not punitive damages).

${ }^{265}$ See Saxton Statement, supra note 261 (noting that the United States and its citizens, as well as Congress and the court system, will not "rest easy until every act of terrorism is stopped").

${ }^{266}$ Sofaer Statement, supra note 107 , at 84. 
judgments through settlement or attachment. From intervention by the U.S. government to complicated legal proceedings identifying "state" assets, these recent decisions have shown that the 1996 amendments have created a right without a clear remedy.

Since Iran dismissed the damage award in Flatow as "politicallymotivated and 'totally lacking objectivity and credibility,"' ${ }^{267}$ any chance of settlement with Iran appeared dismal. Consequently, the Flatow family sought to take advantage of the FSIA's new liberal attachment provisions. ${ }^{268}$ The Flatows were able to identify Iranian assets in the United States, including Iran's old embassy, ambassador's residence, and a building once used by Iranian diplomats. ${ }^{269}$ Yet, when the Flatows attempted to attach these properties, the United States intervened and blocked the attachment.

The United States claimed that these properties are immune from attachment due to the Vienna Convention on Diplomatic Relations. ${ }^{271}$ Pursuant to Article 22(3) of the Vienna Convention, "[t]he premises of the mission [embassy], their furnishings and other property thereof... shall be immune from search, requisition, attachment or execution." ${ }^{272}$ Consequently, as a signatory to this convention, the United States cannot permit the attachment of such property. The United States, however, did not intervene solely to preserve the sacrosanct nature of diplomatic property. The United States also intervened for a very serious practical reason: to protect the attachment of

${ }^{267}$ Jerseyan Seeks Top-Level Aid in Iran Suit, STAR-L,EDGER (Newark, NJ), July 18, 1998, at 6, available in 1998 WL 3431042 (quoting an unnamed source from Tehran).

${ }^{269}$ See 28 U.S.C. $\$ 1610(a)(7)$ (1994) (providing that the property of a foreign state, regardless of whether the property was involved with the act upon which the claim is based, is not immune from attachment in order to satisfy judgments pursuant to the terrorism exception).

${ }^{269}$ See 60 Minules, supra note 1 (noting that these assets were frozen by the United States after Iran seized the American embassy in Tehran in 1979).

${ }^{270} \mathrm{See}$ id. (noting that when Flatow's lawyer tried to seize those assets, federal government attorneys objected).

${ }^{271}$ Vienna Convention on Diplomatic Relations, Apr. 18, 1961, 23 U.S.T. 3227, 500 U.N.T.S. 95 [hereinafter Vienna Convention]. For a detailed analysis of the effect of the Vienna Convention on diplomatic property, see Richard Siegler, Diplomatic Immunity: Minimizing the Risks, N.Y.L.J., July 5, 1995, at 3.

${ }^{272}$ Vienna Convention, supra note 271,500 U.N.T.S. at 108 . These assets are also protected by the 1980 Algiers Accord which ended the hostage crisis with Iran in 1981. Pursuant to this agreement, the "fate of the frozen Iranian assets is to be determined by a special tribunal." J. Scott Orr, Terror Viclim's Azvard in Limbo: U.S. Shields Iran, to Dad's Surprise, STAR-LEDGER (Newark, N.J.), Oct. 21, 1998, at 1, available in 1998 WL 16968261 . 
American properties abroad. ${ }^{273}$ State Department officials warned of adverse reciprocal treatment abroad in enacting the 1996 amendments. ${ }^{274}$ The reciprocal effect on American property and interests abroad has been a concern consistently asserted in opposition to proposals amending the FSIA. ${ }^{275}$

The practical result of U.S. intervention, from the perspective of the victims' families, is that the United States has sided with the terrorist nation against them. ${ }^{276}$ As Stephen Flatow recently said, "I find myself in the surreal position of being opposed by the State Department in my attempts to enforce our judgment against Iranian assets located in the United States." ${ }^{277}$ While some government attorneys have commented that "commitment to the rule of law should not be mistaken for weakness in the face of terrorist violence," ${ }^{278}$ for families that have lost so much, the feeling of abandonment by their own government is a consequence that cannot be ignored. ${ }^{279}$

Congress also believes that the United States has intervened on behalf of the terrorist states. In response, Congress has enacted additional legislation in order to force the United States to aid in the recovery of these judgments. ${ }^{280}$ Senator Lautenberg, in an effort to help

${ }^{273}$ See Terror Victim's Kin Criticizes Clinton. Waiver, WASH. POST, Oct. 26, 1998, at A15 ("If the United States permitted attachment of diplomatic properties, then other countries could retaliate, placing our embassies and citizens overseas at grave risk." (quoting White House Statement)); 60 Minutes, supra note 1 (reporting James Rubin of the State Department as stating, "Diplomatic property must remain sacrosanct, or our embassies and our people o-overseas will be subject to legal challenge, and their property could be confiscated.").

${ }^{274}$ See generally Schiffer Statement, supra note 255.

${ }^{275}$ See id. at 10 ("We should be aware that enlarging the category of property available for pre-judgment attachment and execution in the United States ... invites similar treatment by other countries where our assets may be located.").

${ }^{276}$ See Miller \& Mintz, supra note 221 (stating that Alisa Flatow's family perceives the United States government as steadfast in its effort to block them from attaching the Iranian embassy to satisfy the Flatows' judgment); $c f$. Johnson, supra note 199 (stating that Terry Anderson expects the United States to resist his lawsuit against Iran for its role in his captivity).

$2 \pi$ Stephen Flatow, Keep Fighting, JERUSALEM POST, Sept. 1, 1998, at 10. Flatow further stated that " $[t]$ he State Department stepped in on the side of the Iranians when [his] attorneys asked the United States Marshall's Office in Washington, DC to seize Iranian government real estate located in the US capital." Id.

${ }_{273}$ Miller \& Mintz, supra note 221 (quoting government lawyers in a statement to the judge in the case).

${ }_{279}$ Jeff Jacoby, Clinton's Betrayal of Cuban-Americans, BOSTON GLOBE, Nov. 4, 1999, at A27 ("How can you explain to a mother who has lost her son, a wife who has lost her husband, that their own government is taking the murderers' side?" (quoting Maggie Khuly, Armando Alejandre's sister)).

${ }^{280}$ See 144 CONG. REC. H7418 (daily ed. Aug. 7, 1998) (statement of Rep. Saxton) 
exercise these judgments, ${ }^{281}$ inserted section 117 into the Omnibus Consolidated and Emergency Supplemental Appropriations Act of $1999 .^{282}$ This section amends section 1610 of the FSIA, to permit any property, including property frozen under other U.S. laws, to be "subject to execution or attachment in aid of execution of any judgment relating to a claim for which a foreign state ... is not immune under [the terrorism exception]. ${ }^{283}$ This section includes a waiver, however, which permits the President to "waive the [attachment] requirements of this section in the interest of national security."284 President Clinton exercised his waiver authority over the Flatows' proposed attachment of diplomatic property when he signed the Omnibus Act into law, ${ }^{285}$ claiming that "section 117 would place the United States in breach of its international treaty obligations. It would put at risk the protection we enjoy at every embassy and consulate throughout the world by eroding the principle that diplomatic property must be protected regardless of bilateral relations. ${ }^{286}$ This waiver, in essence, renders all other provisions of the Omnibus Act irrelevant since there are no limitations or restrictions on the President's ability to waive the

("In other words, our State [and Justice Departments were] fighting against our efforts to help the Flatow family cause a price to be paid by Iran .... In other words, our government was protecting the rights of the State of Iran rather than the rights of the Flatow family...." "); see also Alfonse M. D'Amato, Terrorists in Your Pay, N.Y. POST, Sept. 16, 1998, at 35 ("In siding with Iran, the administration has cast its lot with a terrorist regime with a long record of hostage-taking and killing Americans.").

${ }^{281}$ See Daniel Kurtzman, Clinton Blocks Effort to Force Iran to Pay, N.J. JEwISH News, Oct. 29, 1998, at 11, available in $1998 \mathrm{WL} 1139630$ (detailing the circumstances surrounding the passage of $\S 117$ of the Treasury and General Government Appropriations Act of 1999).

${ }_{282}$ Omnibus Consolidated and Emergency Supplemental Appropriations Act of 1999, Pub. L. No. 105-277, § 117, 112 Stat. 2681, $2681-491$.

${ }^{289} I d$. This section also requires the Secretary of State and the Secretary of the Treasury to "fully, promptly, and effectively assist any judgment creditor or any court that has issued any such judgment in identifying, locating, and executing against the property of that foreign state or any agency or instrumentality of such state" if requested by any judgment creditor. $I d$.

${ }^{284}$ Id. § 117 (d), 112 Stat. at 2681-492; see also Tony Snow, Will Bill Fight Any Terrorists?, N.Y. PosT, Sept. 25, 1999, at 17 (acknowledging that Secretary of State Madeline Albright demanded "that the president could waive the statute when vital nationalsecurity interests were at stake").

${ }^{285}$ "Determination to Waive Requirements Relating to Blocked Property of Terrorist-List States," Presidential Determination No. 99-1 of Oct. 21, 1998, 3 C.F.R. $\$ 302$ (1999) ("I hereby determine that the requirements of section 117 ... would impede the ability of the President to conduct foreign policy in the interest of national security .... I hereby waive the requirements of section 117 in the interest of national security.").

${ }^{286}$ Statement on Signing the Omnibus Consolidated and Emergency Supplemental Appropriations Act, 1999, 34 WEEKLY COMP. PRES. DOC. 2108 (Oct. 23, 1998). 
attachments in the interests of national security. It is axiomatic that the attachment of property of a designated state sponsor of terrorism will always threaten national security. All terrorist nations are a threat to national security. If such a nation were not a threat to national security, it would not have been so designated as a terrorist state.

Even when diplomatic property is not the subject of a postjudgment attachment, recent cases demonstrate that execution of any judgment will inevitably result in prolonged, complex legal actions that will deny families closure for years to come. After securing a judgment against Cuba, the litigants in Alejandre attempted to execute their judgment against debts owed to Cuba by telecommunications companies. ${ }^{287}$ The defendant telecommunication companies objected to the writ of garnishment, arguing that they were indebted to Empresa de Telecommunicaciones de Cuba ("ETECSA"), a separate entity from the Cuban government. ${ }^{28}$ Under international public law, "separate juridical entities which are distinct from a sovereign are routinely presumed to enjoy independent status, despite the fact that they may operate openly as governmental instrumentalities." ${ }^{289}$ The court concluded that the debts were owed to ETECSA and not to the government of $\mathrm{Cuba}^{290}$ The court held ETECSA responsible for the government's debt, nevertheless, on the ground that a contrary holding "would prevent Plaintiffs from collecting their court-ordered final judgment... [and] would override the clear legislative policy... in favor of broadening the property which may be executed to compensate" victims of terrorist attacks. ${ }^{291}$ The court deemed the injustice that would result if ETECSA were treated as a separable legal entity as sufficient to overcome the presumption of independent status. ${ }^{292}$ The Court of Appeals for the Eleventh Circuit vacated the lower court's judgment, ${ }^{293}$ concluding that ETECSA enjoys a separate juridical status

${ }^{237}$ See Alejandre v. Republic of Cuba, 42 F. Supp. 2d 1317, 1325 (S.D. Fla. 1999). The plaintiffs filed a motion pursuant to Rule 69(a) of the Federal Rules of Civil Procedure requesting a writ of garnishment against several defendants including: AT\&T, AT\&T of Puerto Rico, Telefonica Larga Distancia de Puerto Rico, MCI International, the Chase Manhattan Corporation, and the Citigroup Inc. See id. at 1326.

${ }^{223}$ See id. at 1326-27 (enumerating the main arguments put forward by the defendant companies in opposition to garnishment).

${ }^{259}$ EPSTEIN ET AL., supra note $155, \$ 7.03(1)$ (b).

${ }^{290}$ See Alejandre, 42 F. Supp. $2 \mathrm{~d}$ at 1335-36.

291 Id. at 1339.

${ }^{292}$ See id. at 1337,1339 (noting that the presumption of independent status may be overcome to prevent fraud or injustice).

${ }^{293}$ See Alejandre v. Telefonica Larga Distancia de Puerto Rico, Inc., 183 F.3d 1277, 1290 (11th Cir. 1999) (vacating the judgment of the district court and remanding to 
from Cuba. ${ }^{294}$ The court acknowledged that the presumption that a governmental instrumentality enjoys independent legal status can be overcome by a showing of injustice, but held that "concern about the injustice of preventing plaintiffs from collecting their judgment" is insufficient to set aside the presumption. ${ }^{295}$

Similar litigation has occurred in the Flatow case. After the Flatows were denied attachment of Iran's diplomatic property in Washington, D.C., Stephen Flatow sought to attach property, allegedly owned by Iran, in Maryland. ${ }^{296}$ The owner of record for the property, however, is the Alavi Foundation, a non-profit foundation incorporated in New York. ${ }^{297}$ Flatow argued that because the foundation is extensively controlled by Iran, it is an instrumentality of Iran and, consequently, the court should lift the presumption of separate existence. ${ }^{298}$ Furthermore, Flatow argued that "American courts should permit enforcement of [state-sponsored terrorism] judgments against non-parties to the underlying litigation when there is evidence that a judgment debtor owns covert property interests in the United States which have been sheltered in an outwardly independent third party.",299

The court denied Flatow's motion for several reasons. First, a corporation is deemed to be a "citizen" of any State in which it is incorporated. $^{300}$ Yet, the FSIA explicitly states that an "'agency or instrumentality of a foreign state" does not include "a citizen of a State of the United States." ${ }^{301}$ Since the Alavi Foundation is a citizen, it is not an instrumentality of Iran and thus cannot be held liable for Iran's debt. ${ }^{302}$ Second, even if the Foundation were an instrumentality of Iran, it is entitled to a presumption of independence from its sov-

dissolve the writ of garnishment).

${ }^{29}$ See id. at 1288 (rejecting plaintiffs' arguments that the presumption of independent status was properly disregarded).

${ }^{295}$ See id. at 1286-87 (noting that such concern would be present in every case in which the plaintiff tries to hold a government instrumentality responsible for the debts of a government).

${ }_{296}$ See Flatow v. Islamic Republic of Iran, 67 F. Supp. 2d 535, 537 (D. Md. 1999).

${ }^{297}$ See id. at 538 (noting that its formation under the laws of the State of New York make it a citizen of New York).

${ }^{293}$ See id. at 540 (arguing that the evidence "strongly suggests" that the Alavi Foundation is a "de facto instrumentality" of Iran).

${ }^{290} I d$. at 539 (quoting Plaintiff's Memorandum in Opposition, at 18).

${ }^{300}$ See id. at 538 (construing 28 U.S.C. $\$ 1332$ (c)(1) (1994)).

sol 28 U.S.C. § 1603(b) (1994); see also Flatow, 67 F. Supp. 2d at 538 (quoting the language of the statute).

${ }_{302}$ See Flatow, 67 F. Supp. 2d at 538. 
ereign. ${ }^{303}$ The court ultimately concluded that Flatow did not overcome this presumption. ${ }^{304}$ Finally, the court was unwilling to adopt Flatow's public policy argument of construing the execution standards of the FSIA to haul third party entities into court when there is proof that the foreign sovereign has some "interest" in the entity. ${ }^{305}$ Such an unprecedented course of action would unduly burden third parties and should not be adopted absent a clear manifestation of legislative intent. $^{305}$

The Flatows are still seeking to execute their judgment. On November 15, 1999, Judge Lamberth, the same judge that awarded the Flatows their $\$ 247.5$ million judgment, ${ }^{307}$ granted the United States' motion to quash a writ of attachment against "all credits held by the United States to the benefit of the Islamic Republic of Iran." court reached this conclusion by finding that the money held by the United States, which was awarded to Iran by the Iran-U.S. Claims Tribunal, was the property of the United States. ${ }^{309}$ Having made this determination, the court held that the suit was, in essence, a suit against the United States, and consequently, absent an express waiver, sovereign immunity bars such suit. ${ }^{310}$ Judge Lamberth, after ignoring the FSIA's prohibition on the award of punitive damages and awarding such damages to the Flatows, ironically concluded that the "court must remain faithful to its proper role within our constitutional system, which requires courts to follow the rule of law, not their own individual conceptions of what is fair and just" and granted the U.S.'s motion to quash the attachment. ${ }^{311}$

The Flatow family returned to court in December, 1999 and at-

${ }^{303}$ See First Nat'l City Bank v. Banco Para El Comercio Exterior de Cuba, 462 U.S. $611,626-28$ (1983) (concluding that duly-created government instrumentalities are entitled to a presumption of independent status).

${ }^{\text {sot }}$ See Flatow, 67 F. Supp. 2d at 540-43 (finding that Flatow failed to demonstrate that Iran exercises day-to-day control over the Foundation or that regarding it as a separate entity would work fraud or injustice).

${ }^{505}$ See id. at 539 (harmonizing $\$ 1605$ (a) (7) of the FSIA with existing FSTA law).

${ }^{206}$ See id. (stating " $[t]$ here is nothing in the language of the provision itself, or the legislative history that indicates that Congress intended 28 U.S.C. Section 1605 (a) (7) to be interpreted differently") (citation omitted).

s07 See supra notes 215-25 and accompanying text (reviewing the damage award).

${ }^{203}$ Flatow v. Islamic Republic of Iran, 74 F. Supp. 2d 18, 19 (D.D.C. 1999).

sos Id. at 20 (" $[\mathrm{C}]$ ontrolling authority dictates the finding that the Treasury funds are U.S. property.").

${ }^{310}$ See id. ("[S]overeign immunity bars their attachment here, as neither the Iranian Assets Control Regulations nor the [FSIA] contain a clear and unequivocal waiver of the United States' immunity.").

${ }^{311} I d$ at 26. 
tempted to levy a writ of attachment against three parcels of real estate owned by the Islamic Republic of Iran, including the former embassy and two NationsBank accounts containing funds generated by the State Department's lease of these properties. ${ }^{312}$ Since the property was part of the former Iranian Embassy, the court concluded that the use of the real property was sovereign, not commercial, in nature. ${ }^{313}$ As such, the property was immune from attachment. ${ }^{314}$ Finally, the court concluded that the two accounts were also immune from attachment since one constituted property of the United States ${ }^{315}$ and the other was not commercial in nature since it related to payment of maintenance and repair expenses of the Iranian mission in the United States. ${ }^{316}$ Having quashed this third attempt to execute the Flatow judgment, even Judge Lamberth concluded that "Flatow's original judgment against Iran has come to epitomize the phrase 'Pyrrhic victory.", "317

On the same day, Judge Lamberth quashed the Flatows' fourth and most recent attempt to execute their judgment. ${ }^{318}$ Here, the Flatows sought to attach an arbitration award issued in favor of Iran by the Iran-United States Claims Tribunal. ${ }^{319}$ Since this award was issued over twelve years ago, Judge Lamberth concluded that the "statute of limitations for confirming the award has expired, [and] neither Iran nor anyone purporting to act on its behalf has cognizable or enforceable property rights in this award. ${ }^{320}$ Consequently, this fourth and most recent attempt ultimately failed as well.

These recently decided cases demonstrate the inevitable consequences in the post-trial phase of suits brought pursuant to the recent amendments. By not requiring the property subject to attachment to

${ }^{312}$ See Flatow v. Islamic Republic of Iran, 76 F. Supp. 2d 16, 18-20 (D.D.C. 1999) (setting forth the facts of the case).

${ }^{313}$ See id. at 22-23 (relying on authority holding that use of property for diplomatic purposes is not commercial activity as a matter of law).

${ }^{314}$ See id. at 18 (noting such "properties and accounts are immune from attachment under the [FSIA]").

${ }^{315}$ See id. at 24 (explaining that, as U.S. property, sovereign immunity bars its attachment).

${ }^{316}$ See id. ("[T]he United States' preservation and protection of the properties ... is a sovereign act.").

${ }^{317}$ Id. at 27.

${ }^{318}$ Flatow v. Islamic Republic of Iran, 76 F. Supp. 2d 16 (D.D.C. 1999).

${ }^{319}$ See FMC Corporation v. The Islamic Republic of Iran, Award No. 292-353-2 (IranUnited States Claims Tribunal Feb. 12, 1987) for background on the money, property, and credits FMC Corp. owes to Iran as a result of the Tribunal's award.

${ }^{320}$ Id. at 2. 
have any connection to the underlying cause of action, diplomatic property and unrelated private property located in the United States will be the subject of lawsuits for years to come. When diplomatic property is seized, the United States will undoubtedly intervene on behalf of the sacrosanct nature of diplomatic property. ${ }^{321}$ On the other hand, when private property is the subject of attachment, innocent third parties will be hauled into court and forced to defend themselves. Forcing victims' families to exercise their judgments in such a piecemeal fashion, without the cooperation of the United States, compels these families to relive their personal tragedies on a daily basis. The end result is that recent litigants know, prior to filing suit, that even if they receive a judgment in their favor, execution of that judgment and the closure that accompanies it will rarely, if ever, occur. ${ }^{322}$ Such a drastic consequence has even led The Washington Post to conclude that the 1996 amendments are a "lie" and should never have been passed. ${ }^{323}$

\section{CONCLUSION}

While it is beyond the scope of this Comment to develop a solution for the problems created by the 1996 amendments to the FSIA, some lessons can be gleaned from both the theory and practice of the private civil suit. From a theoretical perspective, these amendments demonstrate the extraordinary lengths Congress will go to when confronted with a situation over which it feels powerless to change. ${ }^{324}$ While state-sponsored terrorism is one of the most insidious forms of violence and violates every convention of international law, ${ }^{325}$ the 1996 amendments destroy the careful balance between sovereign immunity

${ }^{321} 60$ Minutes, supra note 1 ("Diplomatic property must remain sacrosanct ...." (quoting James Rubin, Spokesman of the State Department)).

${ }^{322}$ See Miller, supra note 199 ("If we get anything it will be years away." (quoting Terry Anderson)).

${ }^{323}$ Editorial, Lawsuits and Terrorism, WASH. POST, Dec. 26, 1999, at B6 ("Congress never should have passed, nor President Clinton signed, a law that could only offer Mr. Flatow justice by depriving the administration of control over important instruments of foreign policy. This law should be repealed.").

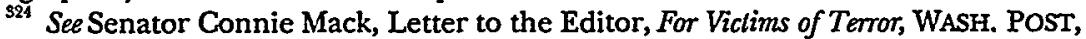
Nov. 6, 1999, at A24 (articulating dissatisfaction with the Clinton Administration's resistance to help successful litigants execute their judgments).

${ }^{325}$ See Statement for the Record of Louis J. Freeh, Director, Federal Bureau of Investigations Before the Subcomm. for the Depts. of Commerce, Justice, and the State, the Judiciary, and Related Agencies of the Sen. Comm. on Appropriations (Feb. 4, 1999), available in 1999 WL 58450 (F.D.C.H.); see also MURPFY, supra note 255, at 58 ("There is no doubt that statesponsored terrorism violates international law."). 
and domestic jurisdiction that Congress struck when it first enacted the Foreign Sovereign Immunities Act. By enacting the FSLA, Congress sought to provide uniform, carefully delineated, and apolitical exemptions from the presumption of immunity. ${ }^{326}$ The recent legislation, however, does not reflect the same careful deliberation. By removing any jurisdictional nexus, ignoring due process concerns, and re-injecting political considerations into determinations of immunity, the 1996 amendments drastically deviate from the steady course Congress has forged.

From a practical perspective, the 1996 amendments confirm that the privatization of the war on terrorism has failed. Stephen Flatow felt empowered by the Flatow Amendment. He commented that the law gave him a weapon. ${ }^{327}$ Yet, the practical consequences of such private suits demonstrate that this weapon is completely ineffective, especially when placed in the wrong hands. State-sponsored terrorism is an international problem that affects a multitude of players. As such, only an international response is appropriate. We must look to international organizations, such as the United Nations, which stand in the unique position of providing a proper forum for redress. The State Department, in opposition to the recent amendments, urged Congress to use the United States's position as "a leader at the UN and elsewhere in marshalling international efforts to combat statesponsored terrorism., ${ }^{328}$

Furthermore, while the initial suits were brought to provide closure and accountability to the families, and to deter terrorist nations from sponsoring terrorist attacks, the recent judgments rendered pursuant to the 1996 amendments demonstrate that the private suit is a futile weapon in effectuating either result. For the victims' families, the recent suits, which have all resulted in default judgments, have failed to provide any accountability. Even the small glimmer of closure that successful litigants receive from their victories in court have proven specious in light of the reality of endless litigation and the U.S. government's resistance to executing judgments. Such protracted litigation and the sense of abandonment it engenders have denied any real closure. As one commentator initially observed, " $[t]$ he ultimate test of success [of the private civil suit] will, of course, lie in the courts.

${ }^{326}$ See supra notes $54-57$ and accompanying text (explaining the congressional purpose behind the law).

${ }^{327}$ See 60 Minutes, supra note 1 ("[The law] gave me a weapon.... I have American jurisdiction over the people who sponsored the terrorist attack which killedAlisa.").

${ }^{32 s}$ Borek Statement, supra note 49, at 12. 
A right after all, is only as good as its exercise., ${ }^{\text {,29 }}$ The recent decisions, along with the concomitant inability to execute the judgments, indicate that the 1996 amendments have clearly created a right without a remedy.

The theoretical implications, coupled with the practical consequences of the private suit, require reexamining the propriety of such a course of action. The private suit has truly come to epitomize a Pyrrhic victory. While these families might be winning the battles in the courtroom, we are still losing the war against terrorism. The devastating consequences of the private suit even prompted Stephen Flatow to say, "If I knew then what I know [now], after spending tens of thousands of dollars trying to get some measure of justice for Alisa, I don't think I would have started this lawsuit." ${ }^{330}$ From the Flatows and the other families touched by the horrors of terrorism-denied accountability and forced to relive their tragedies on a daily basis-to the drastic effect the recent amendments have had on the development of sovereign immunity, experiences with the private suit have demonstrated that the cost of closure is a high price-one that no individual American can afford to pay.

${ }^{529}$ Gerson, supra note 12.

Bes Brian Blomquist, Grieving Dad: Prex Boosts Terror, N.Y. PosT, Sept. 27, 1999, at 15. 
